\title{
Propagation and field assessment of West Virginia native species for roadside revegetation
}

\author{
Sarah B. Wennerberg \\ West Virginia University
}

Follow this and additional works at: https://researchrepository.wvu.edu/etd

\section{Recommended Citation}

Wennerberg, Sarah B., "Propagation and field assessment of West Virginia native species for roadside revegetation" (2005). Graduate Theses, Dissertations, and Problem Reports. 2207.

https://researchrepository.wvu.edu/etd/2207

This Thesis is protected by copyright and/or related rights. It has been brought to you by the The Research Repository @ WVU with permission from the rights-holder(s). You are free to use this Thesis in any way that is permitted by the copyright and related rights legislation that applies to your use. For other uses you must obtain permission from the rights-holder(s) directly, unless additional rights are indicated by a Creative Commons license in the record and/ or on the work itself. This Thesis has been accepted for inclusion in WVU Graduate Theses, Dissertations, and Problem Reports collection by an authorized administrator of The Research Repository @ WVU. For more information, please contact researchrepository@mail.wvu.edu. 


\title{
Propagation and field assessment of West Virginia native species for roadside revegetation
}

\author{
Sarah B. Wennerberg \\ Thesis submitted to the Eberly College of Arts and Sciences \\ at West Virginia University \\ in partial fulfillment of the requirements of the degree of \\ Master of Science \\ in \\ Biology \\ Donna I. Ford-Werntz, Ph.D., Chair \\ James B. McGraw, Ph.D. \\ William N. Grafton \\ Department of Biology \\ Morgantown, West Virginia \\ 2005
}

Keywords: Sabatia angularis propagation, Baptisia tinctoria propagation, Rhus aromatica propagation, Vitis riparia propagation, Parthenocissus quinquefolia propagation, roadside revegetation, roadside restoration 


\title{
ABSTRACT \\ Propagation and field assessment of native West Virginia species for roadside revegetation
}

\author{
Sarah B. Wennerberg
}

Road construction removes vegetation from roadside slopes, making them susceptible to erosion and non-native plant introductions. Erosion Sediment Control (ESC) practices can reduce the annual loss of soil by as much as 100 cubic yards per acre and be cost beneficial. ESC includes using plant species that can germinate and survive on reconstructed areas. In West Virginia, the Division of Highways (WVDoH), uses plant species that are not native, and sometimes invasive, to revegetate newly constructed roadsides. This activity contributes to the growing problem of increased non-native and invasive species in our landscape.

This research investigated the potential use of five WV native species for roadside revegetation: Sabatia angularis, Baptisia tinctoria, Rhus aromatica, Vitis riparia, and Parthenocissus quinquefolia. Chapter two describes seed propagation and field planting studies of $S$. angularis and B. tinctoria. Temperature and chemical pretreatment effects on germination were tested in the greenhouse. Gibberellic acid was found to be the chemical pretreatment that resulted in the greatest percent germination for both species. In the field, germination was compared to greenhouse germination and net population change and mean height were monitored. Baptisia tinctoria had an initial germination rate of $22 \%$, continual increase in net population change, and an overall mean height change of $9.55 \mathrm{~mm}$. Sabatia angularis had an initial germination rate of $15 \%$, declined in net population change throughout the season, and had an overall mean height change of $6.83 \mathrm{~mm}$. Chapter three describes root propagation studies of $R$. aromatica and $V$. riparia. Indole-butyric-acid (IBA) was found to promote root production of cuttings in the greenhouse. In the field, effects of slope aspect and arbuscular mycorrhizae (AM) treatment on survival and mean height change of $R$. aromatica and $P$. quinquefolia cuttings within plots above steep roadside slopes were examined. Despite high mortality, $P$. quinquefolia showed potential for use in roadside revegetation. 


\section{Acknowledgements}

A sincere thank-you to my committee members, Dr. Donna Ford-Werntz, Dr. James McGraw, and William Grafton. To Donna, you have been a very supportive advisor, and I am proud to be your first student. You have a voice-of-reason that has always worked wonders on me when I hit the proverbial wall. I will always be grateful to you for taking me in and allowing me to balance graduate school with personal life's responsibilities. To Jim, thank you for throwing me head first into the pool when I was cautiously testing the waters. Also, thank you for being there to see that I did not drown. You are a person that I will always hold in high regard. To Bill, one of the world's last true gentlemen. Thank you for sharing your experiences with me. You have taught me a lot about West Virginia history, culture, attractions, and its vegetation. I enjoyed traveling around with you and consulting with you about my research. I will think of you every time I bite into a no-bake cookie.

Thanks to other members of the WVDoH Roadside Revegetation Project: Ron Fortney, Neal Carte, Jeff Skousen, John Scencindiver, Rosa Lee Miller, and Christina Venable. Also, thank you to the members of the WVU Department of Biology. You are a very supportive group of people and I appreciate your willingness to share your time with me.

Thank you to Katrina Klugh, C.S. Manish, Sandhya Mohan, and Clint Springer for your brainstorming and feedback sessions. And for what seemed even more valuable at times, your comic relief.

Finally, thank you to my dear husband, Jedd Wennerberg. I am honored to have you by my side. You have celebrated the highs with me, but have also seen me at my worst, and somehow you still like me. I am a lucky girl. Thanks for always seeing the big picture when I was stuck in my tunnel. I could never have done this without you. 


\section{Table of Contents}

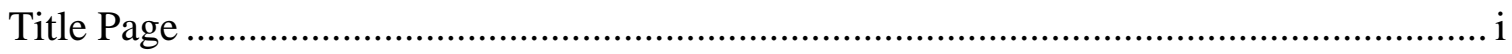

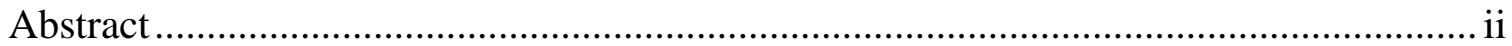

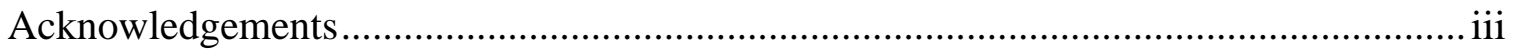

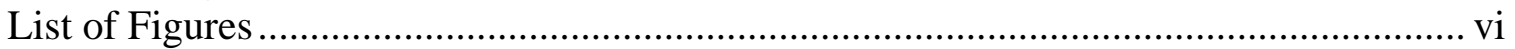

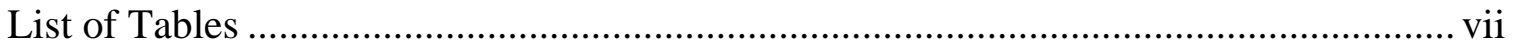

Chapter 1. Introduction............................................................................................... 1

West Virginia Roadside Revegetation: Non-Native and Invasive Species .................... 2

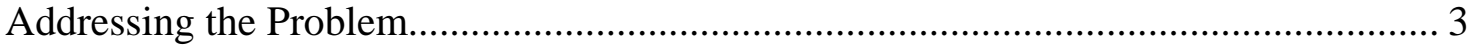

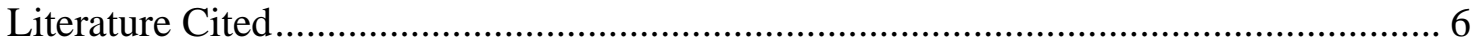

Chapter 2. Propagation and field assessment of West Virginia native plant species, Sabatia angularis (rosepink) and Baptisia tinctoria (yellow false indigo).................... 8

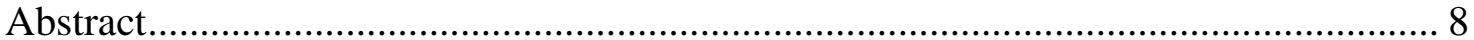

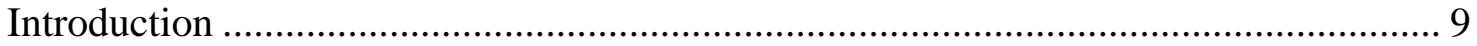

West Virginia Roadside Revegetation: Non-Native and Invasive Species................ 10

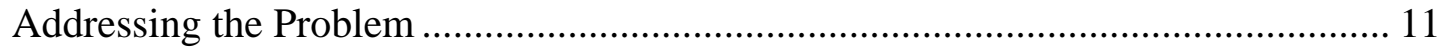

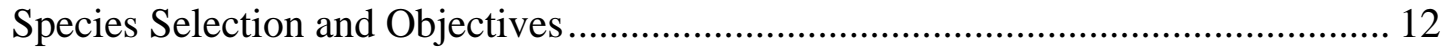

1. Greenhouse assessment of Sabatia angularis and Baptisia tinctoria seed

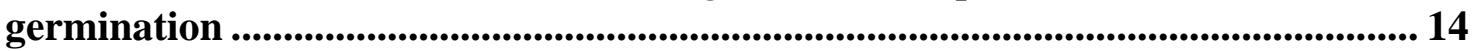

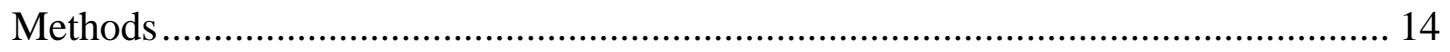

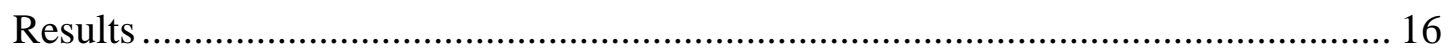

Summary and Discussion: Greenhouse Trials ...................................................... 17

2. Roadside assessment of Sabatia angularis and Baptisia tinctoria germination, net population change and mean height change .............................................................. 18

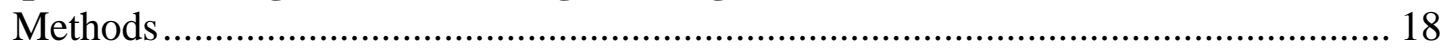

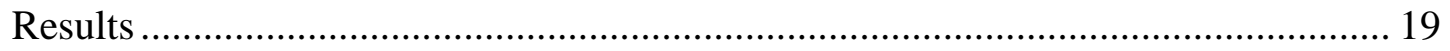

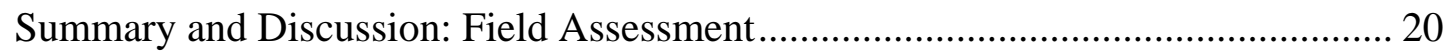

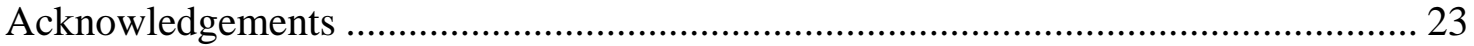

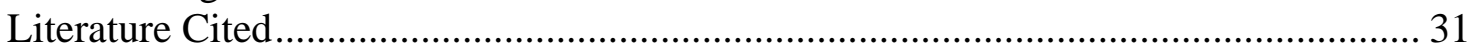

Chapter 3. Propagation and field assessment of Rhus aromatica (aromatic sumac), Vitis riparia (riverbank grape), and Parthenocissus quinquefolia (Virginia creeper)

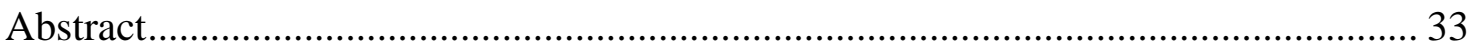

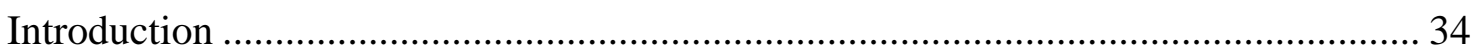

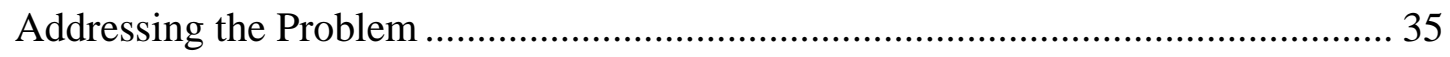

1. Greenhouse assessment of Rhus aromatica and Vitis riparia root production ... 38

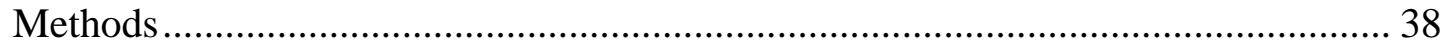

1A. Rhus aromatica and Vitis riparia, Indole-3-acetic Acid Application, spring

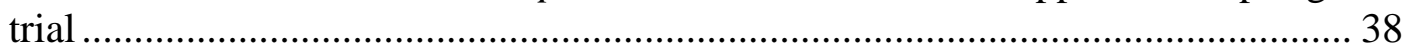

1B. Rhus aromatica and Vitis riparia, Indole-3-acetic Acid Application, summer trial. 
1C. Rhus aromatica and Vitis riparia, Indole-Butyric Acid Application, summer

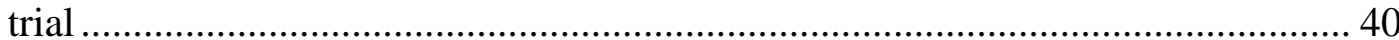

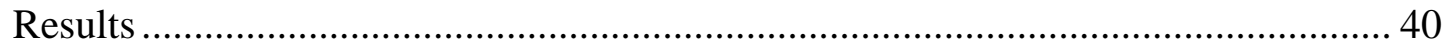

1D. Preparation for spring field studies ............................................................. 41

1E. Vitis riparia, new methods ........................................................................... 42

Summary and Discussion: Greenhouse Trials .......................................................... 42

2. Roadside assessment of Rhus aromatica and Parthenocissus quinquefolia cutting

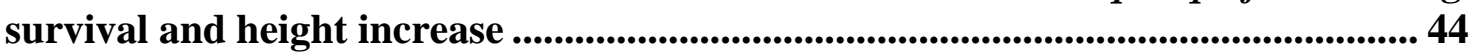

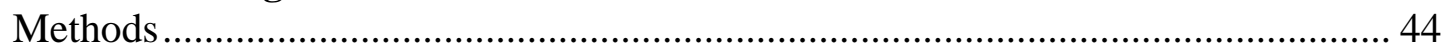

2A. Rhus aromatica and Parthenocissus quinquefolia field studies, pre-rooted... 44 2B. Rhus aromatica and Parthenocissus quinquefolia field studies, direct planting

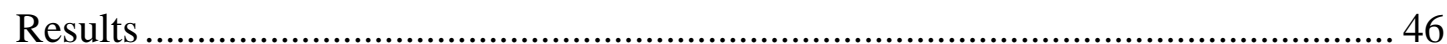

Summary and Discussion: Field Assessment........................................................ 47

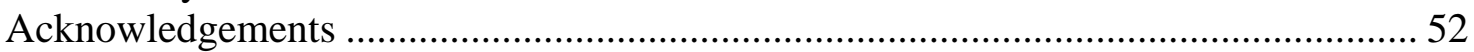

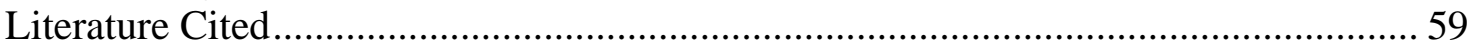

Curriculum Vitae 


\section{List of Figures}

Figure 2.1. Experimental layout for germination assessment of Sabatia angularis and Baptisia tinctoria in petri dishes.

Figure 2.2. Effects of chemical pretreatment on mean percent germination of Sabatia angularis.

Figure 2.3. Pretreatment effects on mean percent germination of Baptisia tinctoria...... 26

Figure 2.4. Experimental layout for field assessment of Sabatia angularis (S) and Baptisia tinctoria (B) seeds.

Figure 2.5. Growth period effects on mean height increase (mm).

Figure 3.1. Root production percentages for Rhus aromatica and Vitis riparia treated with indole-butyric-acid (IBA +/-).

Figure 3.2. Diagram of sites near West Union for field assessment of Rhus aromatica and Parthenocissus quinquefolia.

Figure 3.3. Percent mortality per treatment level within plot $1 \mathrm{~S}$ near West Union for field assessment of Parthenocissus quinquefolia $(\mathrm{Pq})$ and Rhus aromatica $(\mathrm{Ra})$............ 55

Figure 3.4. Mean height change of Parthenocissus quinquefolia $(\mathrm{Pq})$ cuttings treated with arbuscular mycorrhizae (AM) fungi (+/-) in plot 1 S.

Figure 3.4. Mean height change of Parthenocissus quinquefolia $(\mathrm{Pq})$ cuttings treated with arbuscular mycorrhizae (AM) fungi (+/-) in plot $1 \mathrm{~S}$.

Figure 3.5. Latitudinal variations in shortwave energy load, in kilolangleys per year, between pole-facing (north-facing) and equator-facing (south-facing) slopes for each of four slope angles. 


\section{List of Tables}

Table 2.1. Comparison of greenhouse $(\mathrm{GH})$ and field germination rates for Sabatia angularis and Baptisia tinctoria......

Table 2.2. Mean population (mean $\mathrm{P}$ ) per subplot, standard error, net change in population among all plots $(\triangle \mathrm{P})$, and the thinned density of plants for each five-week

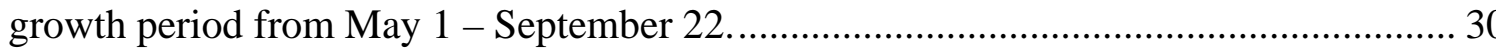

Table 3.1. Summative data of mortality and height change of Rhus aromatica (Ra) and Parthenocissus quinquefolia $(\mathrm{Pq})$ cuttings treated with AM fungi (+/-) in roadside plots located along WV Route 50 near West Union.......................................................... 58 


\section{Chapter 1. Introduction}

Construction and reconstruction of roadways is continuous across the United

States. Although the finished product allows humans easier passage to their destinations, construction of a roadway destroys the vegetation, often altering the terrain of the landscape on which existing plants grow. Removal of vegetation results in erosion problems and leaves roadsides vulnerable to non-native, and sometimes invasive, species. Hazards of roadside erosion include dangers to humans and to the landscape. Erosion weakens roadsides by removing stabilizing soil. As soil moves downward on a slope, rock layers that strengthen the embankment structure become more exposed. Penetration of water into the rock layers causes them to slip, further weakening the slope. Soil, rocks, and mud can move down slopes onto roadways, impeding traffic and creating hazards for motorists, or causing damage to a roadway that sits on top of the slope. Additionally, erosion causes habitat destruction. Plants, and the organisms that rely on them for food and protection, are disrupted by erosion. This decreases the biodiversity within habitat corridors that are often associated with transportation passages.

Erosion Sediment Control (ESC) refers to the revegetation or mechanical restructuring of areas prone to erosion. Erosion Sediment Control can reduce the annual loss of soil by as much as 100 cubic yards per acre (USDA 1974). Furthermore, proper ESC methods can be economical. In 2000, 30 states spent an average of $\$ 9.01$ million on ESC, from an average total construction cost of \$270 million (Mitchell et al. 2000). Erosion Sediment Control costs amount to only 3\% of total costs of construction. 


\section{West Virginia Roadside Revegetation: Non-Native and Invasive Species}

Roadsides stripped of vegetation, regardless of what previously existed on the site, are susceptible to non-native plant introductions. Introduced species have the potential to become invasive in some areas because natural environments and selective pressures have been excluded in new habitats. In the absence of these pressures, invasive species can readily take control of the landscape by out-competing native species for resources. It is difficult to identify whether or not an immigrant species is, or will become, invasive due to the time lag between entering a new region and the time of rapid growth and range expansion (Mack et al 2000). Therefore, introductions of non-native species are potentially risky. Recent awareness of invasive species problems in the United States has led to the identification of characteristics of invasive plant species: invasive species exhibit rapid growth and spread, high reproductive rates, and can quickly overtake an area (Mack et al 2000).

In addition to a plant's own propensity to disperse from site to site, there are also anthropogenic methods of releasing new species into an area. Vehicles can carry nonnative seeds and other plant material hundreds of miles over a short period of time and deposit them on non-established roadside slopes. Beyond accidental introductions, the West Virginia Division of Highways (WVDoH) also contributes to the introduction of non-native species by use in their revegetation mix. However, some of these species are invasive in the Eastern region of the United States as classified by the United States Department of Agriculture, Forest Service (USDA, FS) (1998). The classification system ranks the degree of invasiveness into five categories: 1 (highly invasive), 2 (moderately invasive), 3 (widespread exotic), 4 (locally exotic), and 5 (invasive native species). The 
current WVDoH planting mix includes Coronilla varia (crown vetch, category 1), Festuca elatior (tall-fescue, category 2), and Poa pratensis (Kentucky bluegrass, category 2). Non-native, non-invasive species in the revegetation mix include Lespedeza species (bush-clover species, all in category 3), and Lotus corniculata (birds-foot trefoil, category 3) (USDA, FS 1998). Also, the “Operation Wildflowers” program, sponsored by the WVDoH, includes annual plantings of non-native species. These include corn poppy (introduced to the United States, not reported as naturalized in West Virginia), wild cosmos (native to the United States but not recorded native West Virginia), and sulphur cosmos (introduced to the United States) (Harmon et al. 2001, WVDNR Natural Heritage Program, Elkins, in press). Although none of the species used in "Operation Wildflowers” are invasive, some are non-native to West Virginia and do not accurately represent its vegetation.

\section{Addressing the Problem}

Recent concern over the impacts of invasive species prompted Executive Orders for Greening the Environment to be passed in 1999 and 2000 (EO 13112 and 13148). The orders stated that agencies should take preventative measures to stop the immigration and spread of non-native species and to "provide for ecological control [of invasive species] to minimize [their] economic, ecological, and human health impacts.” As a result, several federal and state agencies, the WV Department of Transportation included, have initiated programs that promote control of noxious and invasive weeds along state and interstate roadways. The WVDoH collaborated with West Virginia University to begin a screening program for finding native plant alternatives that can potentially replace non-native plant species currently included in the WVDoH's revegetation mix. 
This initiative supplements preceding WVDoH programs that focused on corridor connectivity and increased biodiversity (TransSafety 1997). The objectives of this working group were to:

1. Identify native plant species that have potential for use in revegetating roadsides and test methods for cultivating and planting them.

2. Establish plantings in varied habitats along roadways.

3. Evaluate roadside soils in West Virginia to determine cost-effective methods for improving their suitability for native plants and other traditionally planted species. Criteria were established to serve as tools for selecting appropriate candidates for roadside testing. For a WV native plant species to be considered for selection, it had to occur naturally on WV roadsides, and exhibit at least one of the following characteristics. Roadside species should:

- Be effective for erosion sediment control

- Possess high reproductive potential

- Be competitive

- Have related taxa in cultivation

- Not attract deer
- Possess aesthetic qualities

- Improve soils (leguminous)

- Tolerate high light levels

- Not be associated with any known pathogen

- Spread vegetatively (rhizomatous)

Fortney et al. (2000, West Virginia University, Morgantown, WV, in press) identified approximately 250 native species along West Virginia roadsides. These were subjected to the above criteria to generate a list of approximately 25 species. Four of these species, Sabatia angularis (L.) Pursh (rosepink, Gentianaceae), Baptisia tinctoria (L.) R. Br. (yellow false indigo, Leguminosae), Rhus aromatica Ait. (fragrant sumac, Anacardiaceae), and Vitis riparia Michx. (riverbank grape, Vitaceae), were selected for this thesis research. 
The following chapters present the methods and results of this investigation.

Sabatia angularis and B. tinctoria seeds were used for experiments in the greenhouse and roadside plots (Chapter Two). Both species have related taxa in cultivation, but neither are available commercially (USDA, NRCS 2002). Germination protocols were investigated in the greenhouse, while germination and height change were measured in the field. Rhus aromatica and $V$. riparia, and $P$. quinquefolia were utilized in root production studies (Chapter Three) to investigate the potential of transplanting cuttings onto slopes that are especially steep. A greenhouse study tested the effects of hormone application on root production, while cutting survival and height change were measured in the field. 


\section{Literature Cited}

Fortney, R., S. Stephenson, J. Anderson, and W. Grafton. 2000, in press. West Virginia highways as habitats for invasive species. Technical report for the West Virginia Division of Highways.

Harmon, P.J., D.I. Ford-Werntz, W.N. Grafton. 2001, in press. Checklist of the Vascular Flora of West Virginia. Division of Natural Resources, West Virginia Nongame Wildlife and Natural Heritage Program.

Mack, R.N., D. Simberloff, W.M. Lonsdale, H. Evans, M. Clut, and F.A. Bazzaz. 2000. Biotic invasions: causes, epidemiology, global consequences, and control. Ecological Applications 10(3): 689-710.

Mitchell, G.F., T. Guo, and N. Ikiz. 2000. How much does erosion and sediment control for DOT projects cost? Erosion Control Magazine (http://www.forester.net/econ_0301_how.html). Forester Communications, Inc., Santa Barbara, CA 93130.

TransSafety. 1997. Survey finds state DOTs feel biodiversity is a new issue in transportation development projects. Road Management and Engineering Journal, Sept. 2: 1-2 (http://www.usroads.com). TransSafety, Inc., Sequim, WA.

USDA. 1974. Roadside slope revegetation: past and current practice on the national forests. Equipment Development and Test Report 7700-8. Equipment Development Center, San Dimas, California.

USDA, FS. 1998. Eastern region invasive plants, ranked by degree of invasiveness as based on information from states. Forest Service technical paper. USDA-FS, Washington D.C. 
USDA, NRCS. 2002. The PLANTS Database, version 3.5 (http://plants.usda.gov). National Plants Data center, Baton Rouge, LA 70874-4490. 


\title{
Chapter 2. Propagation and field assessment of West Virginia native plant species, Sabatia angularis (rosepink) and Baptisia tinctoria (yellow false indigo).
}

\begin{abstract}
In West Virginia, the Division of Highways (WVDoH), uses non-native, and some invasive plant species for erosion sediment control following construction. Rosepink (Sabatia angularis) and yellow false indigo (Baptisia tinctoria) are two native roadside species whose seeds are currently not available commercially to the WVDoH. The following studies examined 1) seed germination protocols in the greenhouse and 2) the suitability for roadside planting.

Seeds were exposed to temperatures of $0^{\circ} \mathrm{C}, 5^{\circ} \mathrm{C}$, and $10^{\circ} \mathrm{C}$ for three weeks then pretreated with gibberellic acid, water, or sulfuric acid. Gibberellic acid resulted in the greatest germination of S. angularis seeds and the greatest germination of B. tinctoria seeds when combined with a temperature of $0^{\circ} \mathrm{C}$. Five $1 \mathrm{~m} \times 0.5 \mathrm{~m}$ split-plots were laid out in the Interstate 68 (I-68) Interchange at Sabraton, WV. Utilizing greenhouse protocols, seeds of both species were treated and sown into roadside subplots and monitored every five weeks from May 1 to September 22 for germination, net population change, and height change. Baptisia tinctoria had an initial germination rate of 22\%, continual increase in net population change, and an overall mean height change of 9.55mm. Sabatia angularis had an initial germination rate of $15 \%$, declined in net population change throughout the season, and had an overall mean height change of 6.83 mm. The growth periods from July 12 - August 16 and August 16 - September 22 had the greatest mean height change for both species. Baptisia tinctoria showed some potential, but $S$. angularis may not be satisfactory for roadside use.
\end{abstract}




\section{Introduction}

Construction and reconstruction of roadways is continuous across the United

States. Although the finished product allows humans easier passage to their destinations, construction of a roadway destroys the vegetation, often altering the terrain of the landscape on which existing plants grow. Removal of vegetation results in erosion problems and leaves roadsides vulnerable to non-native, and sometimes invasive, species. Hazards of roadside erosion include dangers to humans and to the landscape. Erosion weakens roadsides by removing stabilizing soil. As soil moves downward on a slope, rock layers that strengthen the embankment structure become more exposed. Penetration of water into the rock layers causes them to slip, further weakening the slope. Soil, rocks, and mud can move down slopes onto roadways, impeding traffic and creating hazards for motorists, or causing damage to a roadway that sits on top of the slope. Additionally, erosion causes habitat destruction. Plants, and the organisms that rely on them for food and protection, are disrupted by erosion. This decreases the biodiversity within habitat corridors that are associated with transportation passages.

Erosion Sediment Control (ESC) refers to the revegetation or mechanical restructuring of areas prone to erosion. Erosion Sediment Control can reduce the annual loss of soil by as much as 100 cubic yards per acre (USDA 1974). Furthermore, proper ESC methods can be economical. In 2000, 30 states spent an average of $\$ 9.01$ million on ESC, from an average total construction cost of \$270 million (Mitchell et al. 2000). Erosion Sediment Control costs amounted to only 3\% of total costs of construction. 


\section{West Virginia Roadside Revegetation: Non-Native and Invasive Species}

Roadsides stripped of vegetation, regardless of what previously existed on the site, are susceptible to non-native plant introductions. Introduced species have the potential to become invasive in some areas because natural environments and selective pressures have been excluded in new habitats. In the absence of these pressures, invasive species can readily take control of the landscape by out-competing native species for resources. It is difficult to identify whether or not an immigrant species is, or will become, invasive due to the time lag between entering a new region and the time of rapid growth and range expansion (Mack et al 2000). Therefore, introductions of non-native species are potentially risky. Recent awareness of invasive species problems in the United States has led to the identification of characteristics of invasive plant species: invasive species exhibit rapid growth and spread, high reproductive rates, and can quickly overtake an area (Mack et al 2000).

In addition to a plant's own propensity to disperse from site to site, there are anthropogenic methods of releasing new species into an area. Vehicles can carry nonnative seeds and other plant material hundreds of miles over a short period of time and deposit them on non-established roadside slopes. Beyond accidental introductions, the West Virginia Division of Highways (WVDoH) also contributes to the introduction of non-native species by use in its revegetation mix. However, some of these species are invasive in the Eastern region of the United States as classified by the United States Department of Agriculture, Forest Service (USDA, FS) (1998). The classification system ranks the degree of invasiveness into five categories: 1 (highly invasive), 2 (moderately invasive), 3 (widespread exotic), 4 (locally exotic), and 5 (invasive native species). The 
current WVDoH planting mix includes Coronilla varia (crown vetch, category 1), Festuca elatior (tall-fescue, category 2), and Poa pratensis (Kentucky bluegrass, category 2). Non-native, non-invasive species in the revegetation mix include Lespedeza species (bush-clover species, category 3), and Lotus corniculata (birds-foot trefoil, category 3) (USDA, FS 1998). Also, the “Operation Wildflowers” program, sponsored by the WVDoH, includes annual plantings of non-native species. These include corn poppy (introduced to the United States, not reported as naturalized in West Virginia), wild cosmos (native to the United States but not recorded native West Virginia), and sulphur cosmos (introduced to the United States) (Harmon et al. 2001, WVDNR Natural Heritage Program, Elkins, in press). Although none of the species used in "Operation Wildflowers” are invasive, some are non-native to West Virginia and do not accurately represent its vegetation.

\section{Addressing the Problem}

Concern about the impacts of invasive species prompted the passing of Executive Orders on Invasive Species and Greening the Environment in 1999 and 2000 (EO 13112 and 13148). The orders stated that agencies should take preventative measures to stop the immigration and spread of non-native species and to "provide for ecological control [of invasive species] to minimize [their] economic, ecological, and human health impacts." As a result, several federal and state agencies, the WV Department of Transportation included, have initiated programs that promote control of noxious and invasive weeds along state and interstate roadways. The WVDoH has collaborated with West Virginia University on a screening program to find native plant alternatives that can potentially replace non-native plant species currently included in the WVDoH's 
revegetation mix. This initiative supplements preceding WVDoH programs that focused on corridor connectivity and increased biodiversity (TransSafety 1997). The objectives of this working group are to:

1. Identify native plant species that have potential for use in revegetating roadsides and test methods for cultivating and planting them.

2. Establish plantings in varied habitats along roadways.

3. Evaluate roadside soils in West Virginia to determine cost-effective methods for improving their suitability for native plants and other traditionally planted species.

\section{Species Selection and Objectives}

Criteria were established to serve as tools for selecting appropriate candidates for roadside testing. For a WV native plant species to be considered for selection, it had to occur naturally on WV roadsides, and exhibit at least one of the following characteristics. Roadside species should:

- Be effective for erosion sediment control

- Possess high reproductive potential

- Be competitive

- Have related taxa in cultivation

- Not attract deer
- Possess aesthetic qualities

- Improve soils (leguminous)

- Tolerate high light levels

- Not be associated with any known pathogen

- Spread vegetatively (rhizomatous)

Fortney et al. (2000, West Virginia University, Morgantown, WV, in press) identified approximately 250 native species along West Virginia roadsides. These were subjected to the above criteria to generate a list of approximately 25 species. Two of these species, rosepink (Sabatia angularis (L.) Pursh) and yellow false indigo (Baptisia tinctoria (L.) R. Br.), were selected for investigation into their suitability for roadside revegetation. 
This chapter describes greenhouse and field investigations into the germination of West Virginia native species S. angularis and B. tinctoria for the purpose of post-road construction revegetation. Both species occur along West Virginia roadsides, but neither are available commercially in seed form (USDA, NRCS 2002). Baptisia tinctoria is sometimes available by at least one West Virginia nursery in plant form. Lack of seed availability may be because very little research has addressed germination requirements and rates. Germination success and survival in the field would make them potential candidates for a native seed mix used by the WVDOH for roadside revegetation. If germination protocols can be established, then nursery producers can add the species to their inventory and make them available. The objectives of the following studies were to:

1. Investigate the effects of temperature and chemical pretreatment on seed germination in the greenhouse.

2. Compare germination in roadside environments to greenhouse germination and measure net population and height changes in roadside plots.

Sabatia angularis is a low-growing, protandrous forb that is biennial in the northern portion of its range (Dudash 1991), including West Virginia. It is native to the eastern and lower Midwest regions of the United States (USDA-NRCS, 2002). Its soft pink blooms make the plant aesthetically valuable. Baptisia tinctoria is a perennial forb that reaches a maximum height of $0.76 \mathrm{dm}$. It is native to the eastern portion of the United States (USDA-NRCS 2002). It is a legume, aiding in the enhancement of soil nutrient levels. 


\section{Greenhouse assessment of Sabatia angularis and Baptisia tinctoria seed germination}

The independent variables incorporated into the greenhouse study were species, temperature pretreatment, and chemical pretreatment. Seeds of various species have been found to germinate following dry storage at $2-5^{\circ} \mathrm{C}$ (Baskin and Baskin 1998) or at higher temperatures ranging from $10^{\circ} \mathrm{C}$ to $30^{\circ} \mathrm{C}$ (Heit 1968). Dormant or hard coated seeds have germinated upon cold stratification (Heit 1967) however pretreatment or scarification by use of chemicals can also be utilized (Baskin and Baskin 1998). Experimental temperatures of $0^{\circ} \mathrm{C}, 5^{\circ} \mathrm{C}$ and $10^{\circ} \mathrm{C}$ used in combination with chemical and water pretreatments were selected for this study.

Some species need chemical pretreatment to the seed coat to allow oxygen and water to reach the embryo. Gibberellic acid is used to overcome physiological dormancy and cause rapid germination because it promotes protein synthesis that reactivates enzymes in the embryo (Riley 1987). Other species require scarification by use of sulfuric acid $\left(\mathrm{H}_{2} \mathrm{SO}_{4}\right)$ to overcome mechanical dormancy or "hardseededness," a characteristic that refers to a multi-layered seed coat (Heit 1967). For this reason, GA and $\mathrm{H}_{2} \mathrm{SO}_{4}$ were factors in the experimental design. Finally, some seeds do not require any sort of chemical scarification and can be easily penetrated by water, the final treatment level in the greenhouse study.

\section{Methods}

Sabatia angularis seeds were collected in Flatwoods, West Virginia (Braxton County), near Interstate 79 (I-79) in October 2001. Baptisia tinctoria seeds were collected near the Washington-Jefferson National Forest in eastern West Virginia (Hardy 
County) in October 2002. All seed material was stored in refrigerated temperatures $\left(5^{\circ} \mathrm{C}\right)$ until receiving experimental treatments for germination testing. Sets of seeds were placed in petri dishes during germination tests so that each temperature and chemical combination were assigned to five petri dishes (Figure 2.1). Prior to testing, $93(+/-1.66$ s.e.; $\mathrm{n}=45)$ S. angularis seeds per petri dish $(\sim 450$ seeds per chemical or water pretreatment group) were stored for three weeks in their respective temperature settings in a growth chamber without light. Due to the small size of the seed, an aliquot sample of approximately 93 (measured as a single layer of seeds that fit within the area of one-half the size of a paper-punch hole) was assigned to each dish. Similarly, 20 B. tinctoria seeds per petri dish (100 seeds per chemical or water pretreatment group) were stored in their temperature settings.

At the end of the three-week storage period, subsets of each temperature group were treated with one of the following chemicals: $100 \mathrm{ppm} \mathrm{GA}$, water $\left(\mathrm{H}_{2} \mathrm{O}\right)$, or concentrated $\mathrm{H}_{2} \mathrm{SO}_{4}$, so that a two-way full factorial experiment with five replicates was produced. Gibberellic acid and water-treated seeds received $2.5 \mathrm{~mL}$ of their respective solutions within each petri dish. The solutions remained in the dishes so that the seeds could soak up as much of the treatment solution as possible (they were not poured out post-application). Seeds that were treated with $\mathrm{H}_{2} \mathrm{SO}_{4}$ were soaked in a beaker with just enough $\mathrm{H}_{2} \mathrm{SO}_{4}$ to cover the seeds until the seeds' coloring began to darken (approximately 10 minutes for $S$. angularis and 12 minutes for $B$. tinctoria). The seeds were then rinsed thoroughly with distilled water and placed in petri dishes.

Seeds were placed on a double-layer of Ahlstrom quantitative-grade filter paper in 100 x 15 mm petri dishes (Carolina Biological Supply Co.). One layer of filter paper was 
placed in the lid of each petri dish to filter sunlight and prevent the seeds from drying up in the greenhouse. Five $\mathrm{mL}$ of water was added to the $\mathrm{GA}$ and $\mathrm{H}_{2} \mathrm{SO}_{4}$ treated dishes, while all dishes received $2.5 \mathrm{~mL}$ of Captan's fungal solution and were placed in a greenhouse set at $24^{\circ} \mathrm{C}$. Data collection lasted three weeks. Every two to three days, petri dishes were watered $(2.5 \mathrm{~mL})$ as needed and rearranged on the greenhouse tables to prevent block effect. Additionally, seeds that began to produce mold were removed and recorded. At the end of three weeks, final data was tabulated and a two-way analysis of variance (ANOVA), comparing temperature and chemical pretreatment for each species, was conducted on mean percent germination of each treatment group. S. angularis data was normalized using a power transformation of $0.3\left(\mathrm{Y}^{\prime}=\mathrm{Y}^{0.3}\right)$.

\section{Results}

Chemical pretreatment had a significant effect on S. angularis germination $(\mathrm{p}<$ 0.0001), so that GA application resulted in the greatest mean germination of $11 \%$ (Figure 2.2). There was no significant temperature effect $(p=0.36)$ or interactive effects of temperature and chemical pretreatment $(\mathrm{p}=0.53)$ on percent germination. Since $5^{\circ} \mathrm{C}$ was the temperature used for storing all seeds prior to the germination tests, S. angularis seeds received a treatment combination of $5^{\circ} \mathrm{C}$ and GA application in preparation for field studies. For $B$. tinctoria, $0^{\circ} \mathrm{C}$ pretreatment had significantly greater germination (9\%) by itself ( $p<0.01$, Figure $2.3 \mathrm{a}$ ) and in combination with gibberellic acid $(13 \%, \mathrm{p}=0.03$,

Figure $2.3 \mathrm{~b}$ ). Chemical pretreatment had no significant effect on percent germination (p $=0.61)$. 


\section{Summary and Discussion: Greenhouse Trials}

Sabatia angularis had its highest germination of $11 \%$ when treated with GA.

Germination of many forbs is promoted by GA application, suggesting that these plants do not undergo deep physiological dormancy (Baskin and Baskin 1998) and therefore do not need a strong acid like $\mathrm{H}_{2} \mathrm{SO}_{4}$ for scarification. Since germination greater than $11 \%$ did not occur following GA application, there may be other physiological or life cycle factors affecting germination in S. angularis. Dudash (1990) suggests that inbreeding depression may play a role in decreased fitness in S. angularis populations. Seeds for this experiment were collected from an isolated population in Flatwoods, WV. It is possible that a large portion of the seeds were not viable.

Although S. angularis seeds treated with $\mathrm{H}_{2} \mathrm{SO}_{4}$ had the lowest germination, $\mathrm{H}_{2} \mathrm{SO}_{4}$ was expected to be the chemical treatment with the greatest influence on $B$. tinctoria germination. Concentrated $\mathrm{H}_{2} \mathrm{SO}_{4}$ is used to acid-wash seeds of Cercis canadensis, a legume with seeds similar to $B$. tinctoria. Although $\mathrm{H}_{2} \mathrm{SO}_{4}$-treated $B$. tinctoria seeds had greater germination than S. angularis (which did not germinate at all), they showed considerably less germination than those treated with GA.

The greatest influence on B. tinctoria germination was exposure to zero degree temperatures. Nichols (1934) found that percent germination in B. tinctoria decreased from $98 \%$ to $77 \%$ (21\% difference) following 112 days exposure to outdoor winter temperatures in a cold frame but that the number of days to germinate decreased from 51-329 days to 14-217 days. These findings suggest that low temperatures promote faster germination but not necessarily higher germination percentages. Germination percentages of $0^{\circ} \mathrm{C}$-treated seeds in this greenhouse assessment may be a function of the 
duration of the experiment ( 3 weeks), the time period recommended for greenhouse germination tests by Baskin and Baskin (1998), and not of the temperature exposure.

\section{Roadside assessment of Sabatia angularis and Baptisia tinctoria germination, net population change and mean height change}

\section{Methods}

Five-hundred B. tinctoria seeds and approximately 2325 S. angularis seeds were treated based on the germination study: $B$. tinctoria seeds were stored at $0^{\circ} \mathrm{C}$ for three weeks and treated with gibberellic acid one day before planting, while $S$. angularis seeds continued storage in the growth chamber at $5^{\circ} \mathrm{C}$ and were treated with gibberellic acid one day before planting. On October 12 , 2003, five $1 \mathrm{~m}$ x $0.5 \mathrm{~m}$ split plots were marked out in the Interstate 68 (I-68), westbound interchange at Sabraton, West Virginia (Monongalia County). Standing vegetation was hand-pulled from within each plot. The treated seeds were sown into the plots, so that one-half of each plot contained seeds of each species (Figure 2.4). Each plot contained 100 B. tinctoria seeds and approximately 465 S. angularis seeds. The WVDoH mowed the area at the end of this season, destroying all plots. No data was collected from this planting.

During the second week of April 2004, S. angularis and B. tinctoria seeds were placed in their respective temperature treatments, to remain for three weeks. In midApril of 2004, five new 1m x 0.5m split plots were prepared in the I-68 interchange. Prior to planting, temperature-treated seeds were chemically pretreated with GA and were sown into the Sabraton plots on May 1, 2004. Five weeks after sowing (June 7), the number of germinated seeds and initial height measurements were collected. Every five weeks through September 22, the number of individuals and height measurements were 
recorded. At the beginning of each five-week growth period, the number of plants was thinned to attempt to eliminate density effects so that each species’ plot had an equal number of plants.

\section{Results}

Initial germination levels in the field were compared to greenhouse germination. Greenhouse germination data was collected at 3 weeks while field germination data was collected at 5 weeks. Sabatia angularis had a greenhouse rate of $9 \%$ and a field germination rate of $15 \%$. Baptisia tinctoria had a greenhouse germination rate of $13 \%$ and a field rate of $22 \%$. Table 2.1, which arranges germination rates from lowest to highest for each greenhouse petri dish or field subplot, shows that there appears to be greater variation in greenhouse germination compared to field germination. For instance, the lowest greenhouse germination for S. angularis is $2 \%$ compared to the lowest field germination of $14 \%$. There may have been more variation in the petri dishes because the seeds in each dish were watered as needed. Also, because the dishes of each treatment group were stacked, they did not receive the same amount of light at the same time. Conversely, the roadside plots were in close enough proximity to each other to receive the same amount of water and sunlight.

Net population change was calculated for each five-week growth period from May 1-September 22 (Table 2.2). The greatest mean population of S. angularis seedlings within an individual growth period was 75.8 (out of 465 seeds planted per plot), reaching its peak during the period from June 7 - July 12. Mean population of $S$. angularis declined progressively throughout the growing season, and during the last two periods net population change was negative. The mean population of $B$. tinctoria 
individuals was highest (40.6, out of 100 seeds planted per plot) during the period from August 16 - September 22. Although the factor of increase declined as the season progressed, net population change of B. tinctoria remained positive, resulting in increased mean population throughout the growing season.

From May 1 to September 22, the mean height of B. tinctoria was $16 \mathrm{~mm}$ with a maximum height of $42 \mathrm{~mm}$ and a minimum height of $2 \mathrm{~mm}$. Sabatia angularis had a mean height of $14.2 \mathrm{~mm}$ with maximum and minimum heights of $34 \mathrm{~mm}$ and $2 \mathrm{~mm}$. For

the entire growth season, B. tinctoria seedlings had a mean height change of $9.55 \mathrm{~mm}$ and S. angularis seedlings had a mean height change of $6.83 \mathrm{~mm}$. Analysis of variance was conducted to determine whether there were differential growth period effects on mean height change for either species. For both species, the periods between May 1-June 7 and June 7-July 12 had lower mean height changes than those during the periods of July 12August 16 and August 16-September $22(\mathrm{p}<0.0001$, Figures 2.5 a and b). Statistically higher mean height changes for B. tinctoria were $14.8 \mathrm{~mm}$ and $13.4 \mathrm{~mm}$ during the respective growth periods, while highest mean height changes for S. angularis during the later growth periods were $13.6 \mathrm{~mm}$ and $11.6 \mathrm{~mm}$.

\section{Summary and Discussion: Field Assessment}

In the wild, S. angularis seeds disperse in the fall and germinate late the next spring. By mid-July, rosettes form but flowering does not occur until the following spring (Dudash 1990). During this experiment, rosettes did not form, indicating that growth was much slower in these planted plots compared to natural areas. Baptisia tinctoria had a similar height increase to $S$. angularis, but were taller overall. 
Sabatia angularis seedlings are initially slow-growing and need to be left undisturbed for the first two months (Culling 2000). The first two months in a roadside setting may have negatively affected the overall success of $S$. angularis. A follow-up visit to the site in October 2004 (prior to the first frost) found that the plots were empty of seedlings. Although it was clear that the $S$. angularis populations were beginning to die off as early as July 12, it was unexpected to find no B. tinctoria individuals. Table 2.2 shows the net population change of both species for each of the five-week growth periods. The population of $S$. angularis seedlings began to decrease after the June 7 July 12 period, but B. tinctoria subplots increased in population throughout the entire season. Perhaps a herbivory event or a heavy rainstorm eliminated the seedlings. Also, mortality may have been less apparent with B. tinctoria if ongoing germination counterbalanced mortality so that it was not noticed. It is possible that new germination ceased after September 22 and the small seedlings that were not established succumbed to the duration of the growing season (temperatures ranged from $21^{\circ} \mathrm{C}$ to $26^{\circ} \mathrm{C}$ well into November).

In November 2004 and March 2005, seeds were sown into new plots at this site for observation following fall and early spring plantings. As of April 2005, no germination had occurred. It is possible that both seed stocks have lost viability due to their age. S. angularis was collected in the fall of 2001 and B. tinctoria in fall 2002. However, based on the overall performance of $B$. tinctoria in roadside settings (progressively increased mean population) and overall greater height), the species holds some promise for future use along roadways. However if B. tinctoria mortality is almost equivalent to its germination, then it may not be a useful candidate for WVDoH use. 
Further studies that address field variability of $B$. tinctoria are recommended. For WVDoH purposes, the recommendation is to discontinue candidacy of S. angularis for roadside seed mixes. 


\section{Acknowledgements}

I wish to thank D. Ford-Werntz, J. McGraw, W. Grafton, R. Fortney, N. Carte, A. Norse, J. Skousen, J. Scencindiver, B. O’Hagen, R. Bell, R. Miller, C. Venable, and J.

Wennerberg. This project was supported by the West Virginia Division of Highways and the WVU Eberly College of Arts and Sciences. 
Figure 2.1. Experimental layout for germination assessment of Sabatia angularis and Baptisia tinctoria in petri dishes.

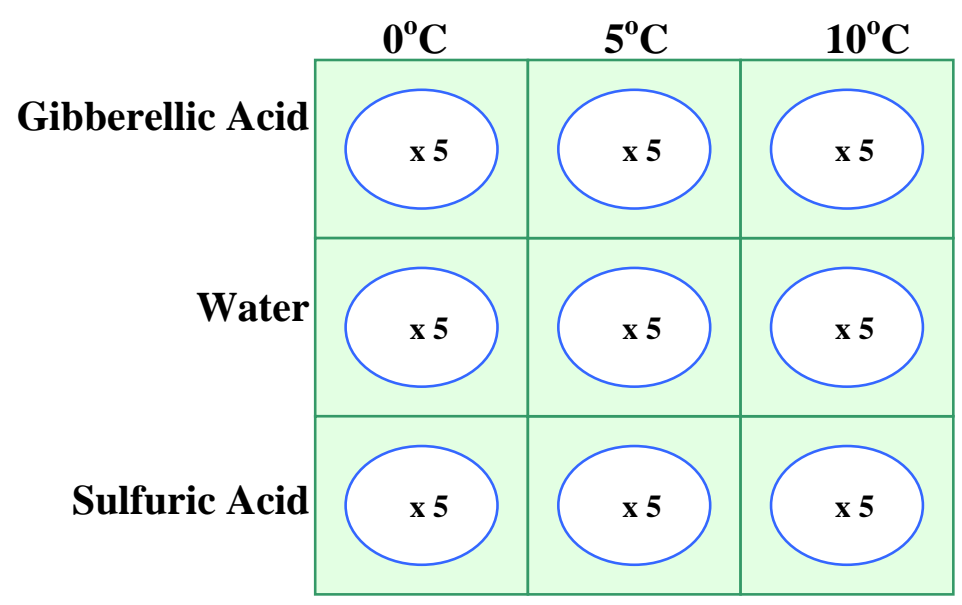

There were 5 petri dishes per treatment group per species. For each dish: S. angularis $(\mathrm{n}=93+/-1.66)$, B. tinctoria $(\mathrm{n}=20)$. 
Figure 2.2. Effects of chemical pretreatment on mean percent germination of Sabatia angularis.

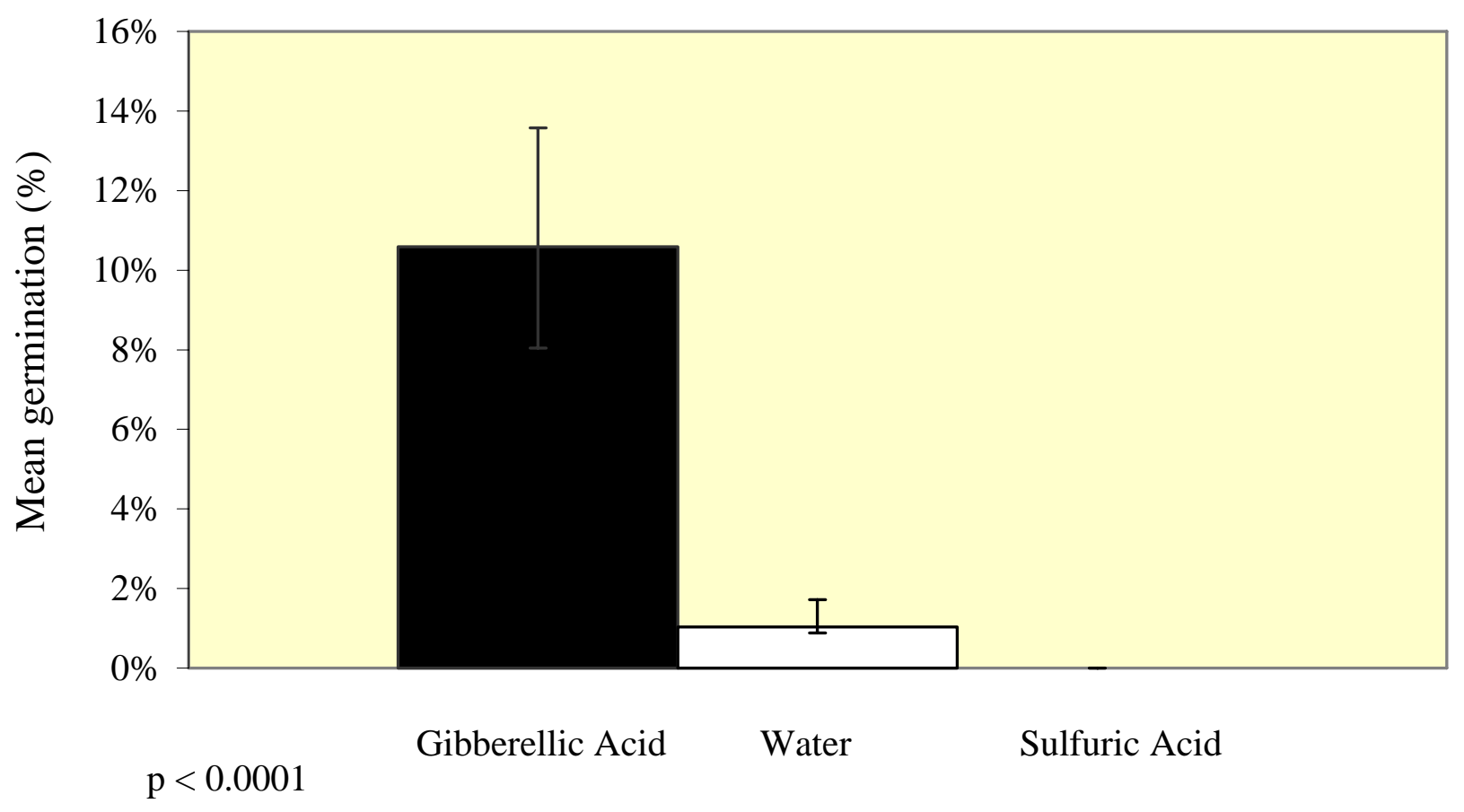


Figure 2.3. Pretreatment effects on mean percent germination of Baptisia tinctoria.

a. Temperature $\left({ }^{\circ} \mathrm{C}\right)$ effects on mean percent germination.

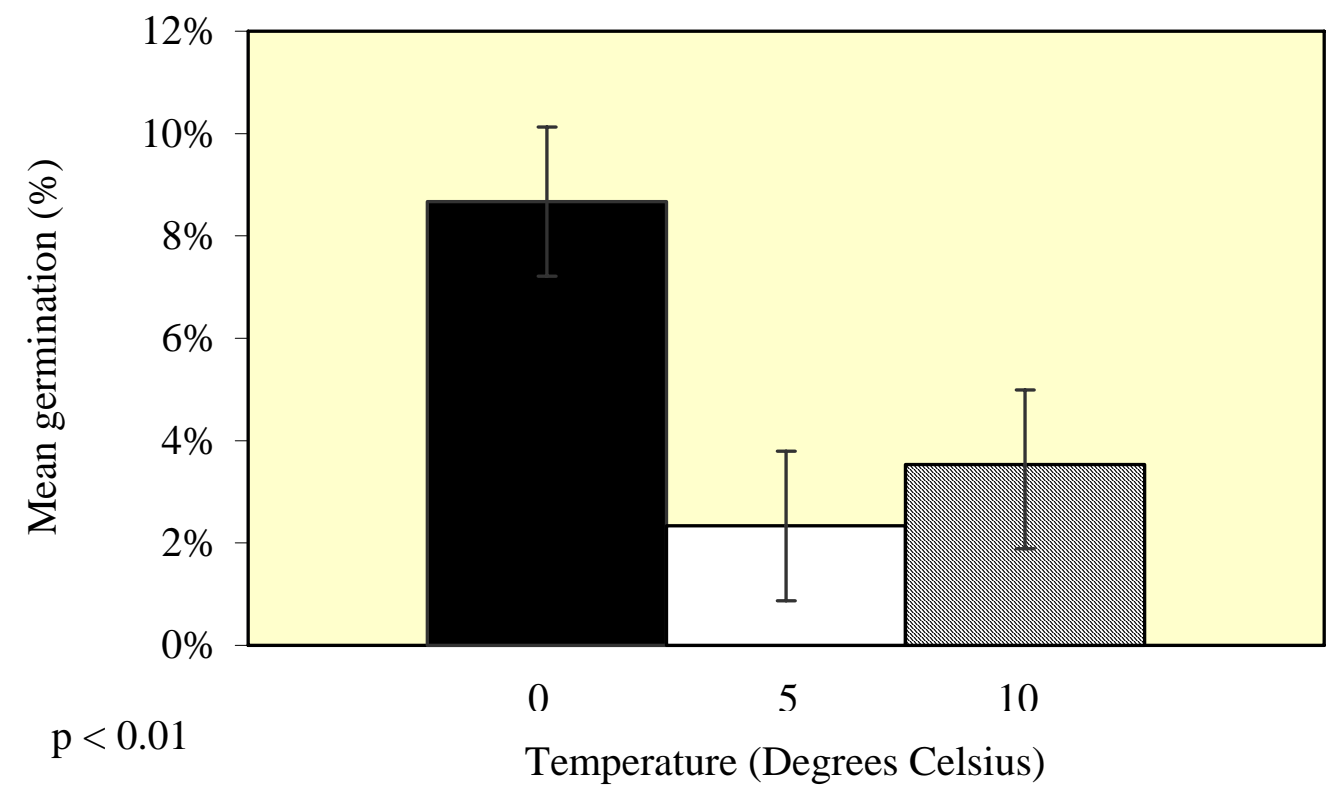

b. Interactive effects of temperature and chemical pretreatment on mean percent germination.

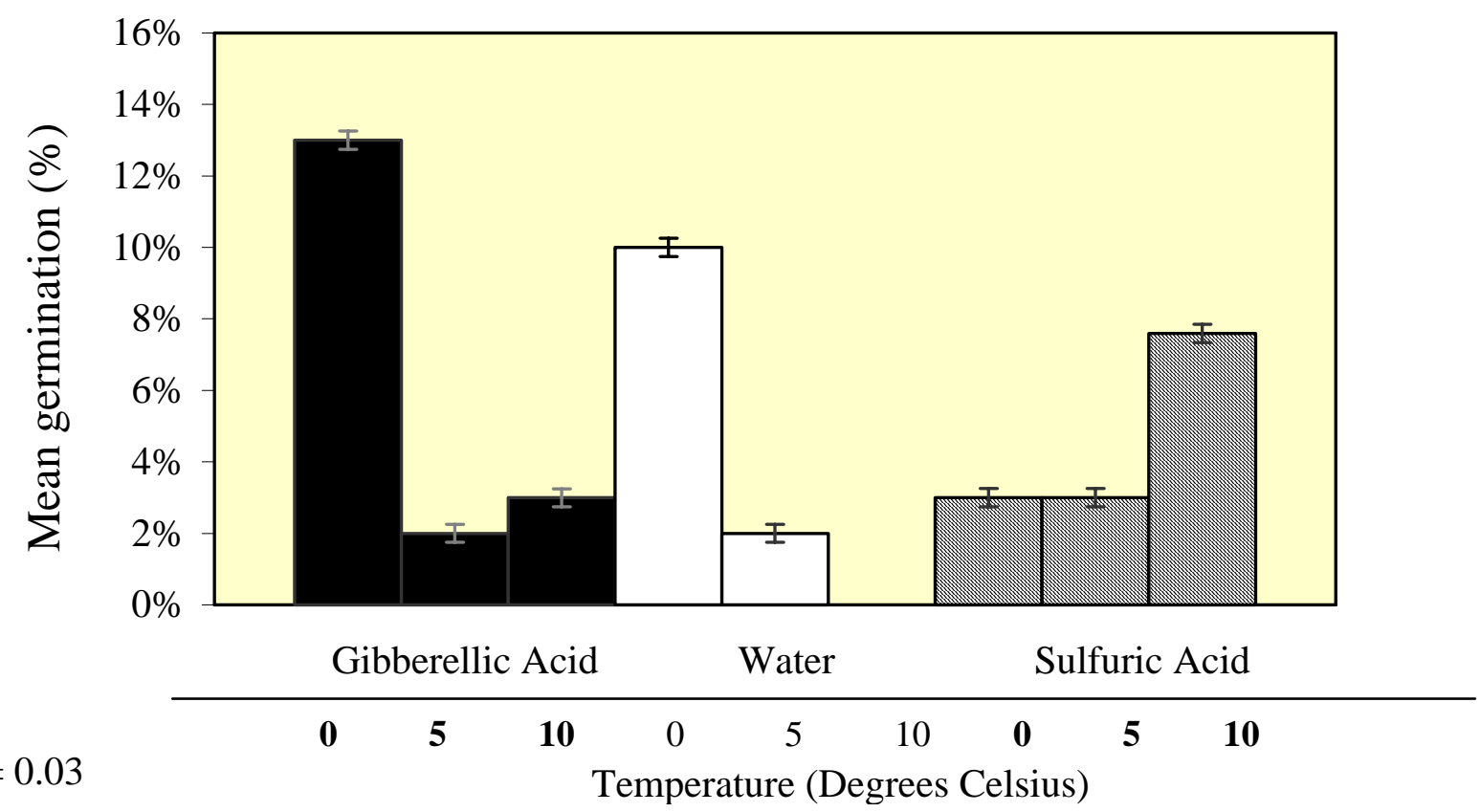


Figure 2.4. Experimental layout for field assessment of Sabatia angularis (S) and Baptisia tinctoria (B) seeds.

The field site was located at the Interstate 68 interchange at Sabraton, WV.

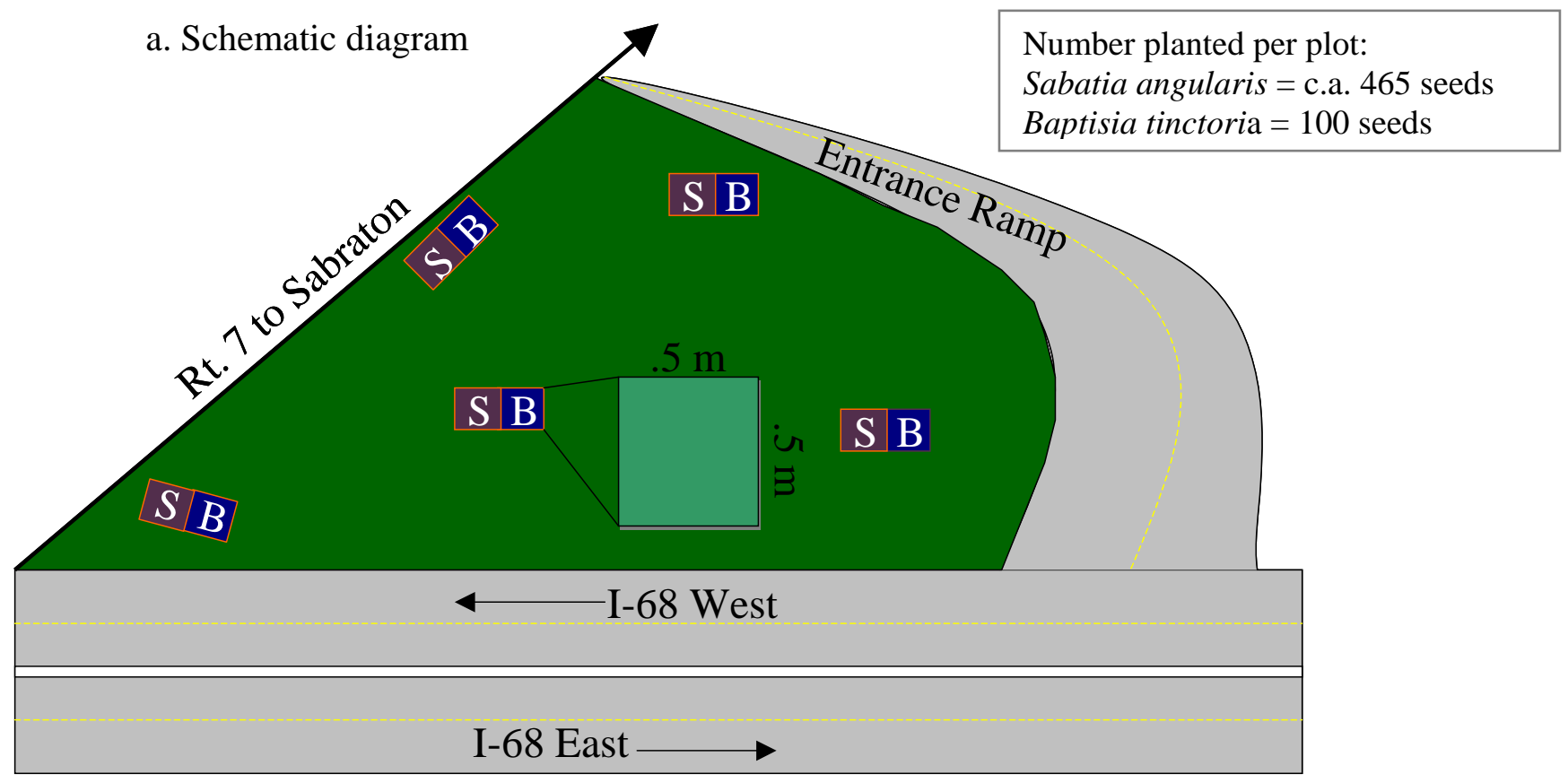


Figure 2.5. Growth period effects on mean height increase (mm).

\section{a. Baptisia tinctoria}

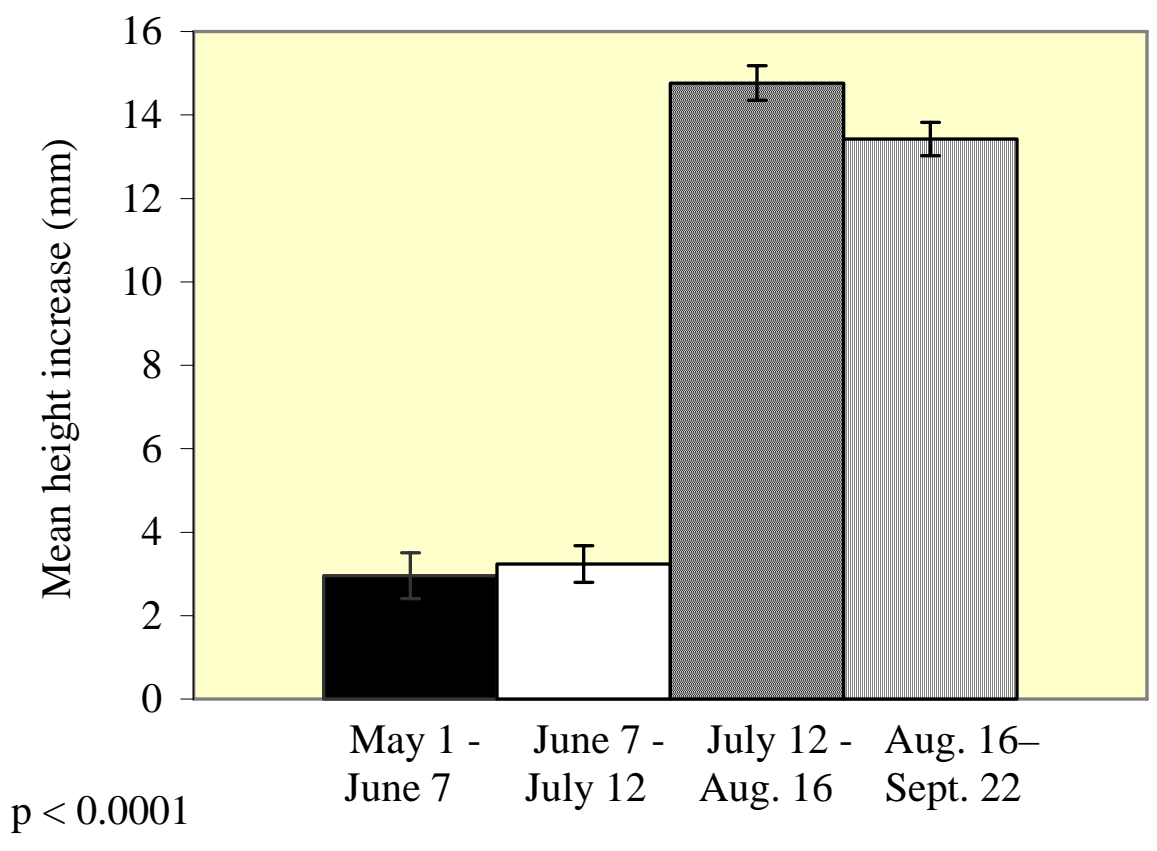

b. Sabatia angularis

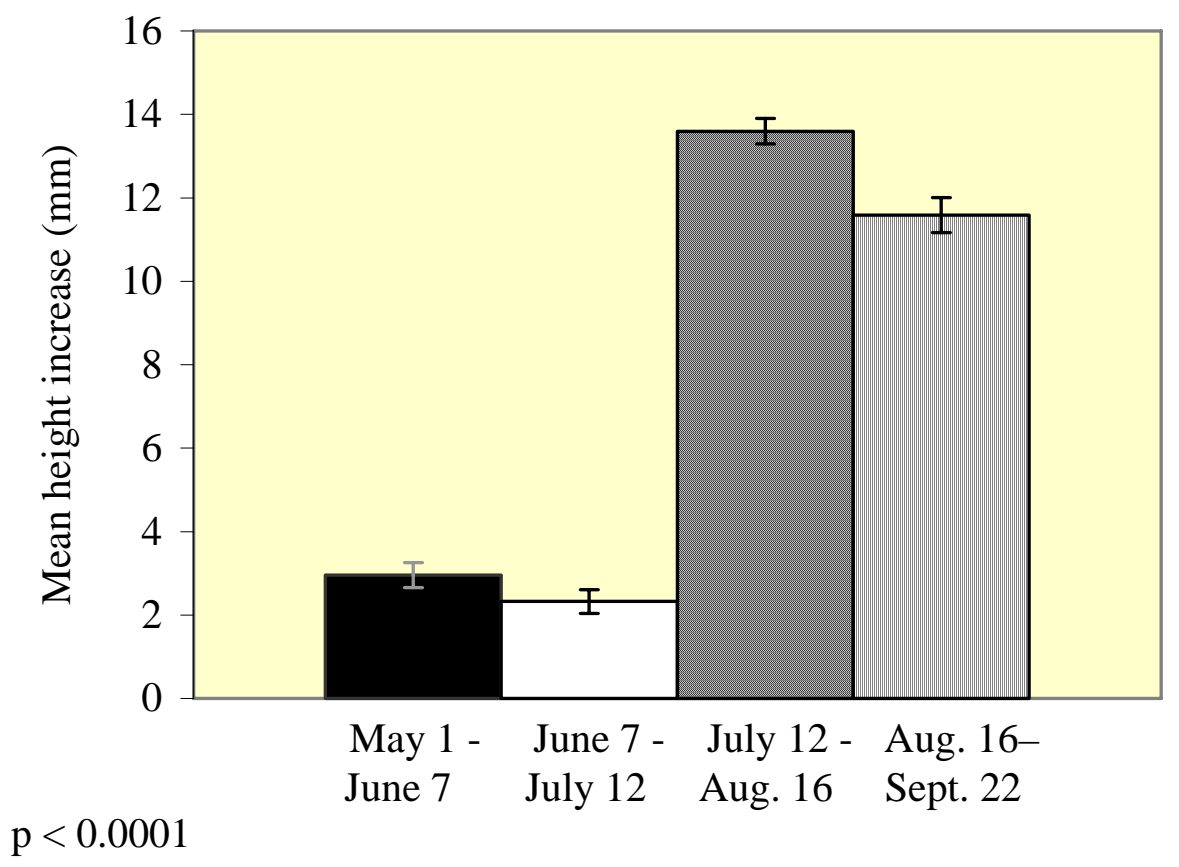


Table 2.1. Comparison of greenhouse $(\mathrm{GH})$ and field germination rates for Sabatia angularis and Baptisia tinctoria.

Values are arranged from lowest to highest rates for comparative purposes. $\mathrm{X}_{n}$ refers to petri dishes in the greenhouse or subplots in the field.

\begin{tabular}{rcccc}
\hline \multicolumn{3}{c}{ Sabatia angularis } & \multicolumn{2}{c}{ Baptisia tinctoria } \\
& $\mathrm{GH}^{*}$ & Field $^{\#}$ & $\mathrm{GH}^{*}$ & Field \\
\hline $\mathrm{X}_{1}$ & $2 \%$ & $14 \%$ & $5 \%$ & $19 \%$ \\
$\mathrm{X}_{2}$ & $8 \%$ & $14 \%$ & $5 \%$ & $20 \%$ \\
$\mathrm{X}_{3}$ & $9 \%$ & $15 \%$ & $15 \%$ & $21 \%$ \\
$\mathrm{X}_{4}$ & $12 \%$ & $16 \%$ & $20 \%$ & $23 \%$ \\
$\mathrm{X}_{5}$ & $16 \%$ & $16 \%$ & $20 \%$ & $25 \%$ \\
\hline Mean & $9 \%$ & $15 \%$ & $13 \%$ & $22 \%$ \\
\hline
\end{tabular}

* Greenhouse rates were calculated from data collected at three weeks.

${ }^{\#}$ Field rates were calculated from data collected at five weeks. 
Table 2.2. Mean population (mean $\mathrm{P}$ ) per subplot, standard error, net change in population among all plots $(\triangle \mathrm{P})$, and the thinned density of plants for each five-week growth period from May 1 - September 22.

a. Sabatia angularis ( $\sim 65$ seeds/plot)

\begin{tabular}{lllll}
\hline & & & & Thinned \\
Period & Mean P & s.e. & $\triangle \mathrm{P}$ & per plot \\
\hline May 1 - June 7 & 67.4 & 1.72 & +337 & 60 \\
June 7 - July 12 & 75.8 & 1.88 & +45 & 70 \\
July 12 - August 16 & 64.6 & 4.17 & -56 & 50 \\
August 16 - Sept 22 & 34.8 & 3.14 & -149 & \\
\hline
\end{tabular}

b. Baptisia tinctoria (100 seeds/plot)

\begin{tabular}{lllll}
\hline & & & & Thinned \\
Period & Mean P & s.e. & $\triangle \mathrm{P}$ & per plot \\
\hline May 1 - June 7 & 21.6 & 1.08 & +108 & 15 \\
June 7 - July 12 & 34 & 1.48 & +62 & 30 \\
July 12 - August 16 & 38.4 & 1.5 & +22 & 34 \\
August 16 - Sept 22 & 40.6 & 1.78 & +11 & \\
\hline
\end{tabular}




\section{Literature Cited}

Baskin, C.C. and J.M. Baskin. 1998. Seeds: ecology, biogeography, and evolution of dormancy and germination. Academic Press, San Diego.

Culling, W., The New England Wildflower Society. 2000. Guide to growing and propagation wildflowers of the United States and Canada. Houghton Mifflin, NY.

Dudash, M.R. 1990. Relative fitness of selfed and outcrossed progeny in a selfcompatible, protandrous species, Sabatia angularis L. (Gentianaceae): A comparison in three environments. Evolution 44(5): 1129-1139.

Dudash, M.R. 1991. Plant size effects on female and male function in hermaphroditic Sabatia angularis (Gentianaceae). Ecology 72(3): 1004-1012.

Fortney, R., S. Stephenson, J. Anderson, and W. Grafton. 2000, in press. West Virginia highways as habitats for invasive species. Technical report for the West Virginia Division of Highways.

Harmon, P.J., D.I. Ford-Werntz, W.N. Grafton. 2001, in press. Checklist of the Vascular Flora of West Virginia. Division of Natural Resources, West Virginia Nongame Wildlife and Natural Heritage Program.

Heit, C.E. 1967. Propagation from seed: Hardseededness-a critical factor. American Nurseryman, reprint from May 151967 issue.

Heit, C.E. 1968. Thirty-five years’ testing of tree and shrub seed. Journal of Forestry 66(8): 632-635.

Mack, R.N., D. Simberloff, W.M. Lonsdale, H. Evans, M. Clut, and F.A. Bazzaz. 2000. Biotic invasions: causes, epidemiology, global consequences, and control. Ecological Applications 10(3): 689-710. 
Mitchell, G.F., T. Guo, and N. Ikiz. 2000. How much does erosion and sediment control for DOT projects cost? Erosion Control Magazine (http://www.forester.net/econ_0301_how.html). Forester Communications, Inc., Santa Barbara, CA 93130.

Nichols, G.E. 1934. The influence of exposure to winter temperatures upon seed germination in various Native American plants. Ecology 15(4): 364-373.

Riley, J.M. 1987. Gibberellic acid for fruit set and seed germination. California Rare Fruit Growers Journal 19: 10-12.

TransSafety. 1997. Survey finds state DOTs feel biodiversity is a new issue in transportation development projects. Road Management and Engineering Journal, Sept. 2: 1-2 (http://www.usroads.com). TransSafety, Inc., Sequim, WA.

USDA. 1974. Roadside slope revegetation: past and current practice on the national forests. Equipment Development and Test Report 7700-8. Equipment Development Center, San Dimas, California.

USDA, FS. 1998. Eastern region invasive plants, ranked by degree of invasiveness as based on information from states. Forest Service technical paper. USDA-FS, Washington D.C.

USDA, NRCS. 2002. The PLANTS Database, version 3.5 (http://plants.usda.gov). National Plants Data center, Baton Rouge, LA 70874-4490. 


\title{
Chapter 3. Propagation and field assessment of Rhus aromatica (aromatic sumac), Vitis riparia (riverbank grape), and Parthenocissus quinquefolia (Virginia creeper).
}

\begin{abstract}
This research investigated methods of roadside revegetation via rooted cuttings using Rhus aromatica (aromatic sumac), Vitis riparia (riverbank grape), and Parthenocissus quinquefolia (Virginia creeper). Plant material was collected from roadsides in West Virginia. Rhus aromatica and V. riparia cuttings were tested in the greenhouse under +/- rooting agent. Log-likelihood analysis revealed that rooting agent containing $0.10 \%$ indole-butyric-acid (IBA) promoted statistically greater root formation. Several failed attempts to mass-produce $V$. riparia cuttings for outplanting in the field resulted in its substitution of $P$. quinquefolia. Rhus aromatica cuttings, prepared with 0.10\% IBA hormone and $P$. quinquefolia plants were planted into subplots on steep, dry roadside slopes near West Union, WV to test the effects of aspect and arbuscular mycorrhizal (AM) fungi on growth and survival. Cuttings in all plots died within two weeks of planting, however six $P$. quinquefolia plants in the south-facing plot of site 1 (plot 1S) resprouted following this initial dieback. A nested nominal logistic fit analysis tested the effects of aspect and AM fungi on plant mortality among plots. There were no differential aspect or AM fungi effects on individual mortality. For surviving $P$. quinquefolia individuals in plot 1S, logistic fit analysis and analysis of variance revealed that there were no AM fungi effects on mortality or on mean height change of $P$. quinquefolia plants. Allelopathy, microsite variation as a function of aspect, or cutting maturity may have been factors in high mortality rates among all plots.
\end{abstract}




\section{Introduction}

Roadsides stripped of vegetation during road construction phases, regardless of what previously existed on the site, are susceptible to non-native plant introductions. Introduced species have the potential to become invasive in some areas because natural environments and selective pressures have been excluded in new habitats. In the absence of these pressures, invasive species can readily take control of the landscape by outcompeting native species for resources. It is difficult to identify whether or not an immigrant species is, or will become, invasive due to the time lag between entering a new region and the time of rapid growth and range expansion (Mack et al 2000). Therefore, introductions of non-native species are potentially risky. Recent awareness of invasive species problems in the United States has led to the identification of characteristics of invasive plant species: invasive species exhibit rapid growth and spread, high reproductive rates, and can quickly overtake an area (Mack et al 2000).

In addition to a plant's own propensity to disperse from site to site, there are anthropogenic methods of releasing new species into an area. Vehicles can carry nonnative seeds and other plant material hundreds of miles over a short period of time and deposit them on non-established roadside slopes. Beyond accidental introductions, the West Virginia Division of Highways (WVDoH) also contributes to the introduction of non-native species by use in its revegetation mix. However, some of these species are invasive in the Eastern region of the United States as classified by the United States Department of Agriculture, Forest Service (USDA, FS) (1998). The classification system ranks the degree of invasiveness into five categories: 1 (highly invasive), 2 (moderately invasive), 3 (widespread exotic), 4 (locally exotic), and 5 (invasive native species). The 
current WVDoH planting mix includes Coronilla varia (crown vetch, category 1), Festuca elatior (tall-fescue, category 2), and Poa pratensis (Kentucky bluegrass, category 2). Non-native, non-invasive species in the revegetation mix include Lespedeza species (bush-clover species, category 3), and Lotus corniculata (birds-foot trefoil, category 3) (USDA, FS 1998). Also, the “Operation Wildflowers” program, sponsored by the WVDoH, includes annual plantings of non-native species. These include corn poppy (introduced to the United States, not reported as naturalized in West Virginia), wild cosmos (native to the United States but not recorded native West Virginia), and sulphur cosmos (introduced to the United States) (Harmon et al. 2001, WVDNR Natural Heritage Program, Elkins, in press). Although none of the species used in "Operation Wildflowers” are invasive, some are non-native to West Virginia and do not accurately represent its vegetation.

\section{Addressing the Problem}

Concern about the impacts of invasive species prompted the passing of Executive Orders on Invasive Species and Greening the Environment in 1999 and 2000 (EO 13112 and 13148). The orders stated that agencies should take preventative measures to stop the immigration and spread of non-native species and to "provide for ecological control [of invasive species] to minimize [their] economic, ecological, and human health impacts.” As a result, several federal and state agencies, the WV Department of Transportation included, have initiated programs that promote control of noxious and invasive weeds along state and interstate roadways. The WVDoH has collaborated with West Virginia University on a screening program to find native plant alternatives that can potentially replace non-native plant species currently included in the WVDoH's revegetation mix. This initiative supplements preceding WVDoH programs that focused 
on corridor connectivity and increased biodiversity (TransSafety 1997). The objectives of this working group are to:

1. Identify native plant species that have potential for use in revegetating roadsides and test methods for cultivating and planting them.

2. Establish plantings in varied habitats along roadways.

3. Evaluate roadside soils in West Virginia to determine costeffective methods for improving their suitability for native plants and other traditionally planted species.

Recently, special attention has focused on roadside areas that are especially steep and as a result essentially barren of vegetation. Plant species that exist on these slopes are able to anchor themselves quickly in the substrate. Many of these species are nonnative and problematic (e.g. invasive Ailanthus altissima). However West Virginia native species also have the potential to live on these sites. For instance, Rhus aromatica (fragrant sumac, Anacardiaceae) has been observed to grow along cut slopes. It has a large root system, and grows rapidly to potentially keep up with the growth of nonnatives. Since natives that grow on steep slopes are specialized for these conditions, their ecological distribution was taken into account when selecting suitable plants for revegetation (McCully 2000) so that no cuttings were transplanted outside of their West Virginia geographic occurrence. The objectives of the following studies were to:

1. Investigate root production against the presence and absence of rooting agent in the greenhouse. 
2. Investigate the effects of species, aspect, and arbuscular mycorrhizal (AM) fungi on growth and survival in the field.

Rhus aromatica and $V$. riparia (riverbank grape, Vitaceae) were selected for study because they both often occur on standard cut slopes, making them potential candidates for use on especially steep slopes. Rhus aromatica produces a large amount of seed, but has a very small and short-lived seed bank (Li et al. 1999) contrasted with a high vegetative reproduction rate. Jonsson and Zak (1975) reported that sumac species aggressively form large colonies via vegetative spread. On steep slopes, utilization of clonal species is desirable because strong roots hold the substrate in place. Rhus aromatica is readily available in seed or plant form at commercial nurseries (USDA, NRCS 2002). Due to specific treatment requirements for germination, plant production via rooted cuttings is recommended (Flemer 1961 in Jonsson and Zak 1975). Vitis riparia is a grapevine species that also exhibits vegetative spread. Grapevines are common in early successional areas (Morano and Walker 1995) and would be appropriate for post-disturbance planting along roadways. Currently, it is commercially available by contract only (USDA, NRCS 2002).

Other factors included in the following studies are the use of rooting agent (containing root-promoting hormones), north- and south-facing aspects, and treatment with AM fungi. Jonsson and Zak (1975) recommended the use of rooting agent for the production of plants from cuttings. Boyce and Neebe (1959) found that different species needed to be used to revegetate north and east facing slopes compared to south and west slopes on strip mine spoil. Finally, disturbed sites are often nonmycorrhizal (Reeves et al. 1979) because the original soil is removed and replaced with new soil upon 
reconstruction of a site. The absence of mycorrhizal fungi in disturbed areas may hinder successional stages by allowing nonmycorrhizal plants to take over, no longer providing an inoculum source for subsequent species. Application of rooting agent was tested in the greenhouse, while the interaction of species, slope aspect, and the application of commercially available AM fungi was tested in field settings.

\section{Greenhouse assessment of Rhus aromatica and Vitis riparia root production Methods}

\section{A. Rhus aromatica and Vitis riparia, Indole-3-acetic Acid Application, spring trial}

In March 2003, approximately 600 cuttings per species were collected from West Virginia roadsides. Rhus aromatica apical cuttings (Schutzman 2004) were collected from Interstate 79 (I-79) at Parkersburg (Wood County). Vitis riparia material was collected near West Virginia Route 119 off of Interstate 68 (I-68), exit 1, at Morgantown (Monongalia County). The cuttings were wrapped in moist towels, placed in black plastic bags, and stored in $10^{\circ} \mathrm{C}$ cold storage without light until planting in the greenhouse. Twelve hundred $115 \mathrm{~mL}$, high-density cone-tainers ${ }^{\mathrm{TM}}$ (Stuewe and Sons, Inc.) were filled with moistened ProMix ${ }^{\circledR}$ potting soil (containing $75-85 \%$ by volume sphagnum peat moss, horticulture grad perlite and vermiculite, dolomitic and calcitic limestone, and a wetting agent), and greenhouse temperatures were set to $22^{\circ} \mathrm{C}$. Cuttings were prepared for planting by making a diagonal cut below the third or fourth node from the top, so that each cutting ranged in length from 10 to $15 \mathrm{~cm}$. Three hundred cuttings per species were dipped in 5000 ppm indole-3-acetic acid (IAA) while the remainder

received no hormone treatment. All cuttings were plugged into the cone-tainers ${ }^{\mathrm{TM}}$ and misted daily. The soil was watered as needed to remain moist. 
Throughout weeks 3 and 4, approximately 40 cuttings were randomly pulled from their pots and examined for callus formation or root production. By week 6, no cuttings had begun the callus phase. The cuttings remained in the greenhouse for several more weeks (with no rooting results) while new methods were investigated. There are several potential reasons for the lack of root production in this experiment. One is that the greenhouse temperature setting may have been too low. Also, collection times may have been incorrect. Varying times of collection have been recommended: in August, well into the growing season (Jonsson and Zak 1975), prior to budbreak (Jonsson and Zak 1975), following the initial phases of bud break or hardening (Hartmann et al. 1997, Grafton, pers. comm.), and in December or early spring when the plants are still without lateral leaves (Huxley 1992, Jonsson and Zak 1975).

\section{B. Rhus aromatica and Vitis riparia, Indole-3-acetic Acid Application, summer trial}

The above process was repeated in June 2003 in a second attempt to produce rooted cuttings. New plant material, 60 cuttings per species, was obtained during the first stages of hardening. Buds had recently broken to produce new leaves. At the time of plugging, all but two apical leaves on $R$. aromatica cuttings and two leaves at the "top" of $V$. riparia vine cuttings were removed. One-half of each collection was assigned to a greenhouse set at $22^{\circ} \mathrm{C}$ or $25^{\circ} \mathrm{C}$. Within each greenhouse, 15 cuttings of each species were treated with IAA dipping paste, the remaining were untreated, and all were placed in cone-tainers ${ }^{\mathrm{TM}}$ containing ProMix ${ }^{\circledR}$ potting soil.

After 5 weeks, no roots had formed in the $22^{\circ} \mathrm{C}$ greenhouse, however some cuttings in the $25^{\circ} \mathrm{C}$ greenhouse that had been treated with IAA were rooted and other plugs showed signs of callusing. It was observed that the medium dried out frequently in 
the greenhouse suggesting inadequate moisture. Another problem in this study may have been the application of IAA, which promotes root growth only at small concentrations. Plants utilize larger concentrations of IAA at apical regions, and so root production of these cuttings may have been inhibited by 1000 ppm of IAA (Wang et al. 2004). Indolebutyric-acid (IBA) was found to be an appropriate hormone alternative to IAA (Hartmann et al. 1997). Indole-butyric-acid concentrations for $R$. aromatica cutting production vary from 3,000 ppm (Schutzman 2004) to 10,000 ppm (Hartmann et al. 1997). Low root production prevented field studies during the 2003 growing season but prompted the next series of greenhouse experiments.

\section{C. Rhus aromatica and Vitis riparia, Indole-Butyric Acid Application, summer trial}

In August 2003, twenty R. aromatica and thirty V. riparia cuttings were collected and started in a shaded greenhouse set at $25^{\circ} \mathrm{C}$. One-half of each collection was treated with a commercially available rooting powder containing $0.10 \%$ by mass (1000 ppm)

indole-butyric acid (IBA). All cuttings were plugged into cone-tainers ${ }^{\mathrm{TM}}$ containing peat moss and sand (to retain underground moisture), watered twice daily, and misted two to three times daily. A sheet of plastic was used to tent moisture around the plants.

\section{Results}

Four weeks after hormone application, the number of rooted cuttings was measured. For R. aromatica, $80 \%$ of the cuttings that were treated with IBA produced roots while there was 30\% root production among untreated cuttings. Similarly, $73 \%$ of IBA-treated $V$. riparia cuttings produced roots while $33 \%$ of untreated cuttings produced roots. Log-likelihood analysis was conducted on the number of rooted cuttings. Indole- 
butyric-acid application had a significant effect on increased root production for both $R$. aromatica and $V$. riparia $(\mathrm{p}=0.02$ and $\mathrm{p}=0.03$ respectively, Figure 3.1$)$.

\section{D. Preparation for spring field studies}

In early September 2003, three-hundred cuttings of $R$. aromatica and V. riparia were collected and started in the greenhouse in preparation for outplanting during the spring of the 2004 growing season. A diagonal cut was made directly below the third or

fourth node so that each cutting was 10 to $15 \mathrm{~cm}$ long. All but two apical leaves were removed, root dip containing 1000 ppm IBA was applied, and cuttings were plugged into cone-tainers ${ }^{\mathrm{TM}}$ containing peat moss and sand. The cuttings were watered twice daily and misted two to three times daily and had a plastic tent placed around them in a shaded greenhouse set at $25^{\circ} \mathrm{C}$.

By January 2004, no R. aromatica cuttings had rooted, possibly because soil moisture levels were too low. Twice-daily watering may not have been frequent enough to provide adequate moisture to the cuttings. Also, the greenhouse in which the cuttings were placed was not equipped with a misting system to mist a large quantity of plants; rather, the cuttings were misted manually daily. From previous experiments, dormant $R$. aromatica cuttings did not produce roots so it was decided that $R$. aromatica material should not be recollected until April.

Vitis riparia cuttings became moldy and had to be removed from the greenhouse. Research into V. riparia cultivation indicated that vine material could be collected while dormant, anytime after leaves have shed and prior to springtime bud swelling (Rombough 2002). During the period between January and May 2004, V. riparia cultivation was investigated and attempted. 


\section{E. Vitis riparia, new methods}

New methods required that bundles of cuttings be wrapped in moist paper towels, enclosed in black plastic bags, and placed rooting side down on a heated surface with a constant temperature of $27^{\circ} \mathrm{C}$ to $29^{\circ} \mathrm{C}$ (Rombough, 2002). The WVU Herbarium's plant dryer, a raised wood box with a grid wire base, was used. Light bulbs beneath the base provide bottom-up heat to the rack. Using 75-watt bulbs, the temperature at the wire surface, where the plant bases were placed, reached $24^{\circ} \mathrm{C}$.

Forty V. riparia cuttings were collected in February 2004 and wired together into bundles of ten cuttings. Twenty stems were dipped into rooting powder containing 1000 ppm IBA while the remaining twenty were untreated. Bundles were then wrapped with moist paper towels, enclosed in black plastic, and placed in the heat rack. The bundles were checked three times per week for callus formation. Also at these times, the paper towels were remoistened when necessary and the insides of the bags were misted with a spray bottle.

After four weeks, all stems in the non-treated bags had produced mold and were discarded. The treated stems did not produce mold but also did not callus. A second attempt was made in March with similar results. It is likely that the drying rack did not create enough heat for the cuttings to produce roots.

\section{Summary and Discussion: Greenhouse Trials}

Although small numbers of cuttings had a positive reaction to IBA application, large amounts of $R$. aromatica and $V$. riparia cuttings could not be propagated within the time constraints of the study. The probable reason is that soil moisture levels were too low for root formation to take place. Daily watering practices required that the soil be soaked to the point that water was running from the underside of the pots. In the 
afternoon, during the second watering session, this was repeated because the soil would dry out quickly.

Also, appropriate propagation facilities require heated mist beds that can apply low levels of moisture several times per minute. This moisture provides several protective elements to cuttings during root production. First, it allows for evaporation from the leaf surface rather than transpiration (water loss) from within leaves. Second, misting keeps leaf surfaces cooler, offering protection against wilting damage (Hartmann, et al. 1997). Finally, intermittent (rather than constant) misting maintains higher soil temperatures needed for root production (Hess and Snyder 1954). Hartmann et al. (1997) suggests that cuttings be misted every 17-20 seconds for a duration of 3 to 15 seconds. Suboptimal manual watering and misting produced considerably weak and underdeveloped plants for transplantation into field subplots.

Experimental attempts to promote rooting in $R$. aromatica cuttings required three trials. Application of IBA hormone to R. aromatica cuttings resulted in an $80 \%$ root production rate in a greenhouse set at $25^{\circ} \mathrm{C} . V$. riparia had $73 \%$ root production in the same conditions. Due to very specific handling procedures of $V$. riparia, it was difficult to maintain cuttings in large quantities. New methods were investigated, attempted, and not successful. As a result, V. riparia was replaced by Parthenocissus quinquefolia (Virginia Creeper, Vitaceae) for use in field studies. Parthenocissus quinquefolia is a vine that is widespread throughout the state, including roadsides. It was selected because of its apparent ability to spread in many directions from its point of origin. Also, it is presently used in restoration projects. 


\section{Roadside assessment of Rhus aromatica and Parthenocissus quinquefolia cutting survival and height increase}

\section{Methods}

In early April 2004, 300 R. aromatica cuttings were collected, treated with IBA, and plugged into cone-tainers ${ }^{\mathrm{TM}}$ in the greenhouse to root for field studies. At the end of two months, most $R$. aromatica cuttings had callused and began to form small roots. The strategy for preparing $P$. quinquefolia was to collect vine material from the Morgantown area, cut approximately $30010-15 \mathrm{~cm}$ segments of the vine, plug the existing rootlets into a peat moss and sand medium, and hold the plants in the greenhouse until field planting. All cuttings were given two months in the greenhouse prior to outplanting.

\section{A. Rhus aromatica and Parthenocissus quinquefolia field studies, pre-rooted}

Field sites were located along U.S. Route 50 near West Union (Doddridge

County). Two sites were selected, each having a bench slope on the north and south sides of the highway. Each slope had one plot, located along the edge of the bench cut that was further divided into subplots (Figure 3.2 a). The plots were named as follows: 1S (site 1, south-facing aspect), $1 \mathrm{~N}$ (site 1, north-facing aspect), 2S, and $2 \mathrm{~N}$. The cut below plot $1 \mathrm{~S}$ had a $37^{\circ}$ slope while the cuts below all other plots had $31^{\circ}$ slopes. The soil pH for plot 2S was 5.7 while plots $1 \mathrm{~S}, 1 \mathrm{~N}$, and $2 \mathrm{~N}$ had a soil $\mathrm{pH}$ range of 7.3 to 7.7 .

Plots were marked off near the edge of each bench cut. A $0.5 \mathrm{~m} \times 4 \mathrm{~m}$ plot was divided into eight $0.5 \mathrm{~m}^{2}$ subplots (Figure $3.2 \mathrm{~b}$ ). One week prior to planting, black landscaper fabric (GardenPlus ${ }^{\circledR}$, Lowe’s) was laid down over the plots to prepare each site. The purpose of the fabric was to prevent overcrowding of newly planted cuttings by existing vegetation within the plots. All plot areas were surrounded by Poa pratensis 
(Kentucky bluegrass), Coronilla varia (crownvetch), and Lespedeza virginica (slender lespedeza). Poa pratensis was growing within the plot areas when they were delineated.

On June 17 2004, 128 R. aromatica and P. quinquefolia cuttings (64 individuals each species) from the greenhouse (see section 2A) were planted into the plots. Four cuttings per species were randomly assigned to each $0.5 \mathrm{~m}^{2}$ subplot. Two subplots of both species were randomly assigned to each arbuscular mycorrhizae (AM) fungi treatment (+/-; MycorTree ${ }^{\circledR}$ Root Dip, Plant Health Care, Inc.). The root dip contained four endomycorrhizal species (Glomus clarum, G. etunicatum, G. intraradices, and Entrophospora columbiana), one ectomycorrhizal species (Pisolithus tinctorius), rhizosphere bacteria, and soil amendments. After cuttings received their respective treatments, a cross-shaped slit was cut into the overlaying fabric, and the cuttings were transplanted into their assigned plots. Each individual was watered and left to remain untouched for the duration of the growing season. Initial heights and the number of leaves present were recorded. One week following planting, all transplants had senesced and appeared dead.

\section{B. Rhus aromatica and Parthenocissus quinquefolia field studies, direct planting}

One week later (July 1 2004), $R$. aromatica and $P$. quinquefolia material was

collected once again but taken directly to the field sites. All R. aromatica material was dipped into rooting powder containing $0.10 \%$ by weight (1000 ppm) IBA.

Parthenocissus quinquefolia material had rootlets along the vine at the time of collection. The second planting followed the original planting scheme. AM-treated cuttings were planted in subplots that had been previously treated with AM fungi to avoid residual 
mycorrhizal effects from the initial planting. Initial heights and the number of leaves present were recorded.

One week following the second planting, all but five cuttings in plot $1 \mathrm{~S}$ had dried up and apparently died. The five surviving plants were $R$. aromatica; four had received AM treatment and one had not. Although the plants were still alive, they had also experienced wilting damage by the sun and heat. Each plant initially had 3-4 apical leaves, but they had lost all but one and height decreased from wilting. By July 15, these plants also died. However, by August 6, every P. quinquefolia subplot in plot 1S had at least one plant that had sprouted leaves and increased in height since the first week's dieback (6 of 16 plants). Two cuttings were AM-treated while four were not.

Final mortality, height, and leaf number measurements were recorded on September 4 (Table 3.1). All analyses were conducted on data between the dates of July 7 and September 4 (62 days). July 7 was selected as the date from which to compare final measurements because it was the date of the recorded die-back.

\section{Results}

A three-way nested nominal logistic fit analysis was conducted on mortality data among plots. Plot was nested within the effect of site by aspect and subplot was nested within the interactive effects of species, mycorrhizae, and plot(site $\mathrm{x}$ aspect). There were no significant model effects (species, aspect, or AM) on mortality following nominal logistic fit analysis $($ chisquare $=26.76, \mathrm{p}=0.64)$. A three-way nested ANOVA was intended to analyze overall change in height of individual plants among all plots from July 7 through September 4 (62 days). However, due to zero growth in all plots but 1S, overall height change data could not be normalized for analysis. 
Plot 1 S exhibited $20 \%$ total survival (all P. quinquefolia plants) while all other plots had $100 \%$ mortality. Within plot 1 S, a one-way nominal logistic fit tested the effect of AM fungi on P. quinquefolia mortality. Of the P. quinquefolia survivors in plot 1S, those treated with AM fungi had 75\% mortality but the effect did not differ from 50\% mortality of untreated cuttings ( $p=0.30$, Figure 3.3 ). A one-way ANOVA tested the effects of AM fungi on mean height change of surviving $P$. quinquefolia plants. Those treated with AM fungi had a mean height increase of approximately $1.5 \mathrm{~cm}$ but did not differ significantly from the $2.3 \mathrm{~cm}$ mean height change of untreated cuttings $(\mathrm{p}=0.47$, Figure 3.4).

\section{Summary and Discussion: Field Assessment}

The 2004 growing season's climate conditions in West Virginia were favorable for plant growth. Statistical analysis showed that the experimental factors (species, aspect, and mycorrhizae) did not differentially influence mortality. However, the plot effects were untestable (they were not replicated on slopes), suggesting that a more appropriate experimental design needs to be selected. Other factors may have played a more important role in the high mortality rate. These factors include microsite effects as a function of aspect, maturity and overall plant health of the cuttings, and allelopathy and/or competition by neighboring plant species.

Rhus aromatica cuttings survived longer in the $1 \mathrm{~S}$ plot compared to all others and six out of sixteen P. quinquefolia cuttings regenerated following an initial die-back. Resprouting on these harsh sites was interesting and led to the investigation of possible reasons for it. Since there were no significant model effects on mortality, among plot variation may have had a greater effect than any of the factors tested. The sites are hot during summer months. Plot $1 \mathrm{~S}$ was positioned on an area that had slightly more tree 
cover than the other plots. The shade may have provided more protection so that the cuttings were less exposed to direct sunlight and heat stress. Due to the shade cover, the two south-facing plots may have had more of a difference between each other than conditions between north- and south-facing plots.

Eldridge et al. (1991) investigated soil surface characteristics (bare ground, litter, gravel, sand or cryptogram crust) and their potential effects on seedling establishment in relation to mature shrub proximity. Cohort survival patterns differed across microsites with differing time patterns of the study sites. The authors suggested that moderate litter levels contributed to seedling survival by lowering soil temperatures and raising soil moisture levels. If this assumption is correct, then it might partially explain high mortality across all of the West Union plot areas. Existing vegetation may have acted as a soil insulator, reducing soil temperatures below the temperature necessary for cuttings to generate roots. The area surrounding $1 \mathrm{~S}$ had less herbaceous vegetation compared to all other plot areas and may have provided more favorable conditions for root production and a greater potential for growth. Conversely, higher shading on plot 1S may have provided some protection against over-heating of black landscaper’s fabric. On the other plots, direct sunlight onto the fabric may have led to soil temperatures that were too high. Among plot variation may have been a result of unfavorable soil temperatures, but whether they were too high or too low is difficult to determine.

Incident radiation intensity on north-facing slopes is lower than on south-facing and bottomland aspects (Robinson 1966). Also, surface temperatures (below $10 \mathrm{~cm}$ above the soil surface) are lower on north-facing than on south-facing slopes. Holland and Steyn (1975) found that shortwave energy loads are greater and have greater 
variation between north- and south-facing slopes in mid-latitudinal ranges than in polar or equatorial regions (Figure 3.5), suggesting that aspect influences variation in vegetation so that plant growth is greater on south-facing slopes. This is consistent with what was observed at the field sites. Generally, as shortwave energy loads increase, so do slope environment temperatures providing an environment favorable to plant growth.

In the mid-latitudes, aspect effects on plant growth are offset by decreasing water storage capacity of soils on slopes steeper than $15-25^{\circ}$ (Holland and Steyn 1975). In West Virginia, low moisture levels on steep roadside slopes may be a result of slope steepness rather than differing temperatures as a result of slope aspect. Therefore slope steepness and concomitant water stress may have contributed to plant mortality more than slope aspect. The more established herbaceous vegetation surrounding plots $1 \mathrm{~N}, 2 \mathrm{~N}$, and 2S might have been able to out-compete for the little moisture that was available in the soil. Soil moisture and temperature were not monitored, but it is recommended for further studies.

Other factors that may have led to high mortality on the field sites are allelopathic effects from surrounding species and the age (and associated health) of the cuttings that were transplanted into subplots. The roadside plots near West Union were surrounded by large amounts of vegetation on the benches. The most prominent species were Poa pratensis, allelopathic Coronilla varia and Lespedeza virginica. The level of interference by each species is unknown and may depend on their conspecifics. Ridenour and Callaway (2001) investigated competitive and allelopathic interference of Centaurea maculosa, an invasive species, on plant growth and population decline of Festuca idahoensis, a native prairie grass species. Centaurea maculosa was found to be an 
aggressive competitor of $F$. idahoensis when its root exudates were not alleviated by growth medium containing activated carbon. The study suggests that alleopathic interference may influence the competitive balance between species.

High mortality rates could have been a result of allelopathic effects, but are also likely due to competition for limited resources, and even more probably because the cuttings were not adequately rooted when planted ( $R$. aromatica was un-rooted and $P$. quinquefolia had small rootlets). It may be possible that young cuttings are less likely to tolerate allelopathic effects compared to older transplants. However, it seems that other factors such as heat and moisture stress were more likely perpetrators.

An informal visit to the sites in June 2005 revealed more interesting findings. Of the six P. quinquefolia plants that were alive in plot $1 \mathrm{~S}$ in September 2004, five overwintered and were producing leaves. In addition, four new plants were resprouting. Three of the four had been treated with AM fungi root dip, bringing the total of AMtreated cuttings to five individuals (compared to four untreated individuals). Given the delayed recovery of $P$. quinquefolia cuttings, it is possible that they were not dead from the initial planting (Section 2A).

If this is the case, then the $R$. aromatica cuttings that had been pre-rooted in the greenhouse prior to the first planting may have had a chance of recovery after the first die-back too. Also, $R$. aromatica cuttings may have had a better chance of survival if they had been left in the greenhouse over the summer and transplanted in the fall (September to early October). The roots would have been larger and the plants may have been better prepared to undergo winter dormancy and resprout in the spring. 
For WVDoH purposes, it is recommended that both species be further investigated. Parthenocissus quinquefolia shows potential in that it can be collected and immediately planted along roadsides. Rhus aromatica might have more potential if it is not planted during hot summer months. Spring and fall planting trials are suggested.

Other recommendations for field methods are to use burlap or landscaper fabric of a color other than black and to start young transplants by seeds and not cuttings. 


\section{Acknowledgements}

I wish to thank D. Ford-Werntz, J. McGraw, W. Grafton, R. Fortney, N. Carte, A. Norse, J. Skousen, J. Scencindiver, R. Bell, R. Miller, C. Venable, and J. Wennerberg. This project was supported by the West Virginia Division of Highways and the WVU Eberly College of Arts and Sciences. 
Figure 3.1. Root production percentages for Rhus aromatica and Vitis riparia treated with indole-butyric-acid (IBA +/-).

IBA application had a significant effect on root production of both Rhus aromatica $(\mathrm{p}=0.02)$ and Vitis riparia $(\mathrm{p}=0.03)$.

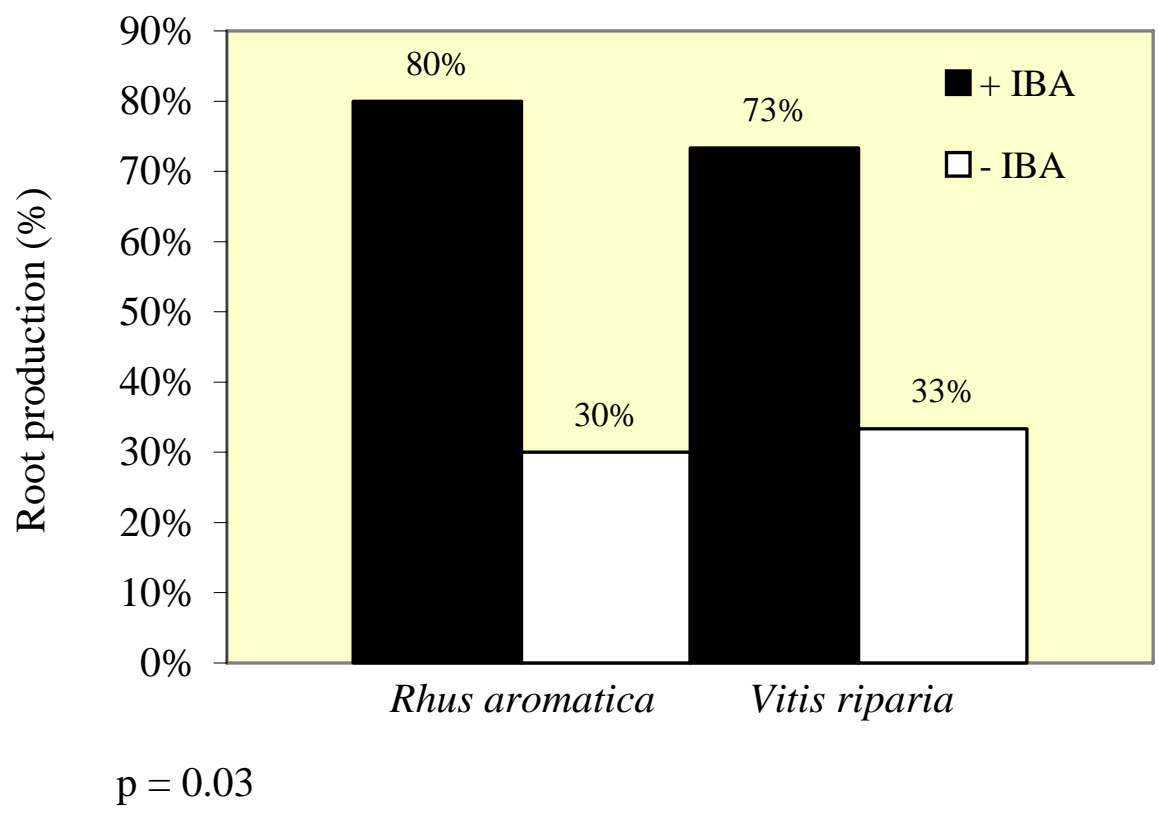


Figure 3.2. Diagram of sites near West Union for field assessment of Rhus aromatica and Parthenocissus quinquefolia.

Each site had a north- and south-facing slope. Each slope had one plot that was further divided into subplots.

a. Diagram showing the layout of one site. There were two sites in this study.

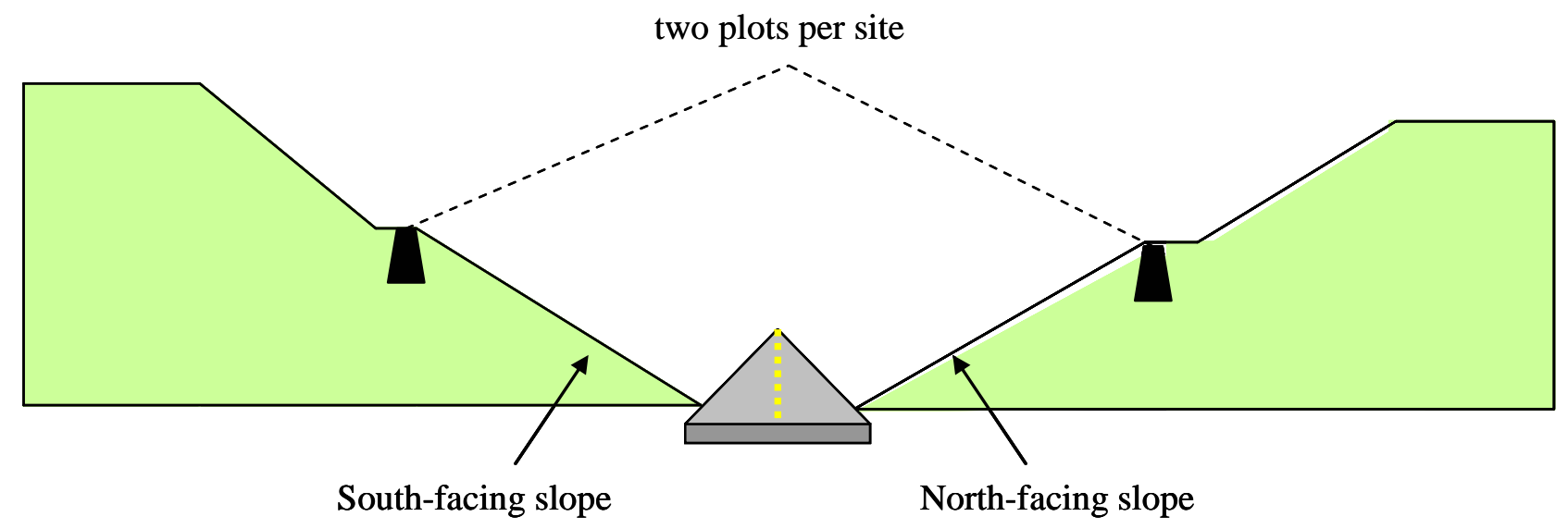

b. Planting scheme for Rhus aromatica (ra) and Parthenocissus quinquefolia (pq) with arbuscular mycorrhizal fungi treatments (+/-).

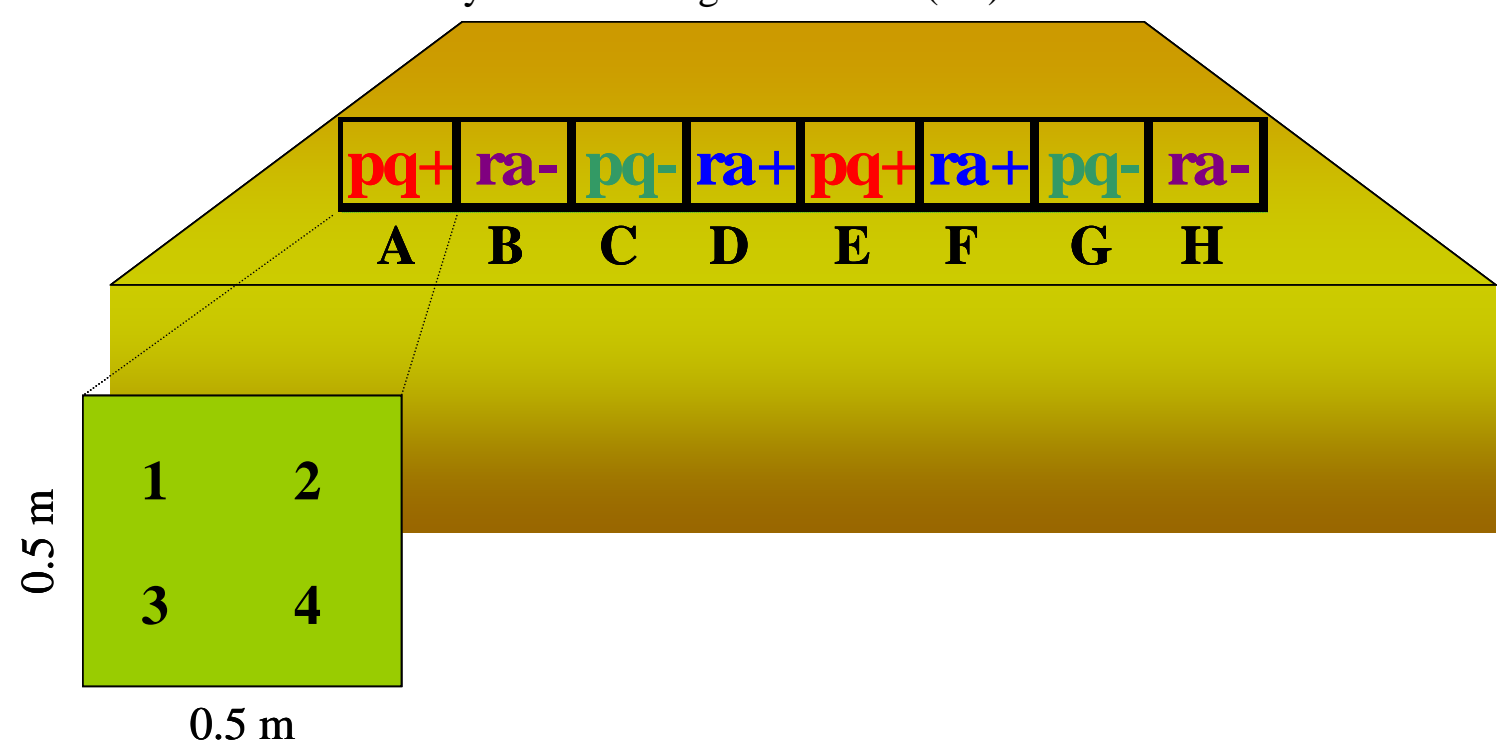


Figure 3.3. Percent mortality per treatment level within plot $1 \mathrm{~S}$ near West Union for field assessment of Parthenocissus quinquefolia (Pq) and Rhus aromatica (Ra).

Treatment levels include species (Pq or $\mathrm{Ra}$ ) and AM fungi application (+/-).

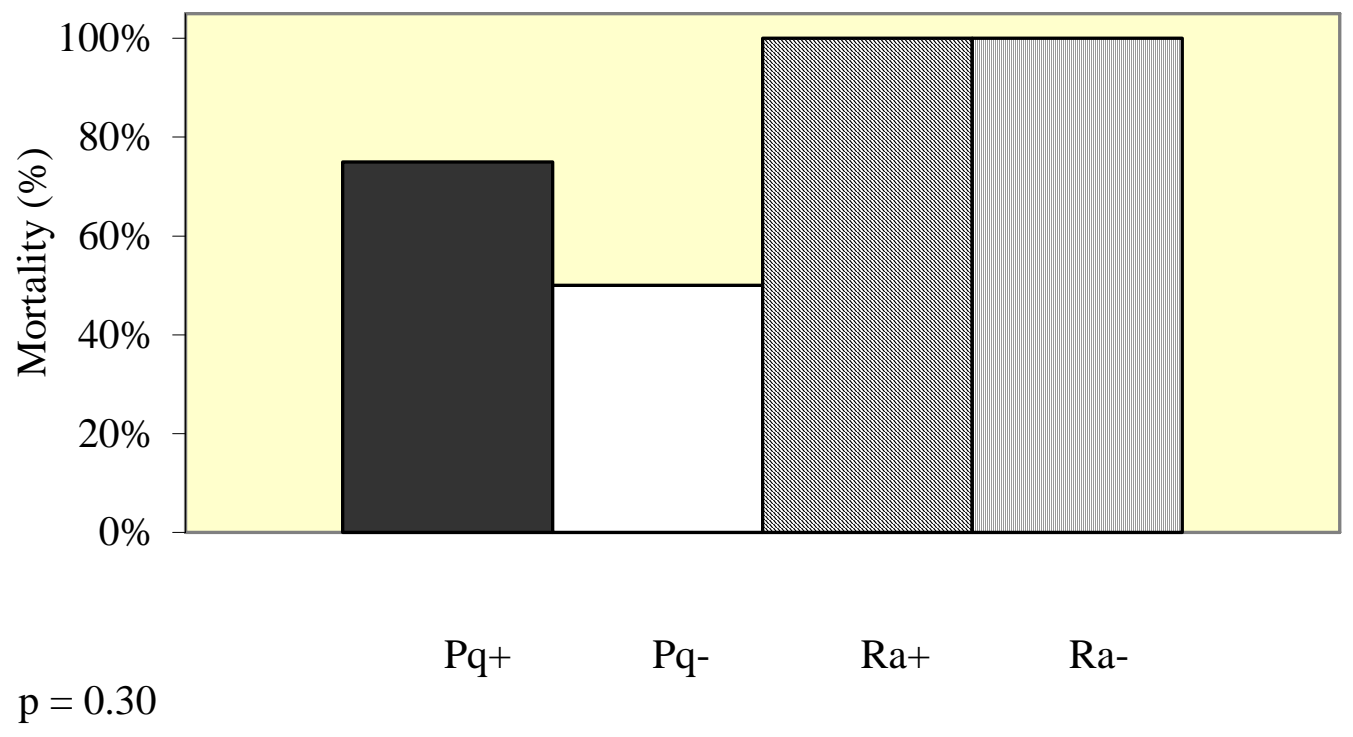


Figure 3.4. Mean height change of Parthenocissus quinquefolia $(\mathrm{Pq})$ cuttings treated with arbuscular mycorrhizae (AM) fungi (+/-) in plot 1S.

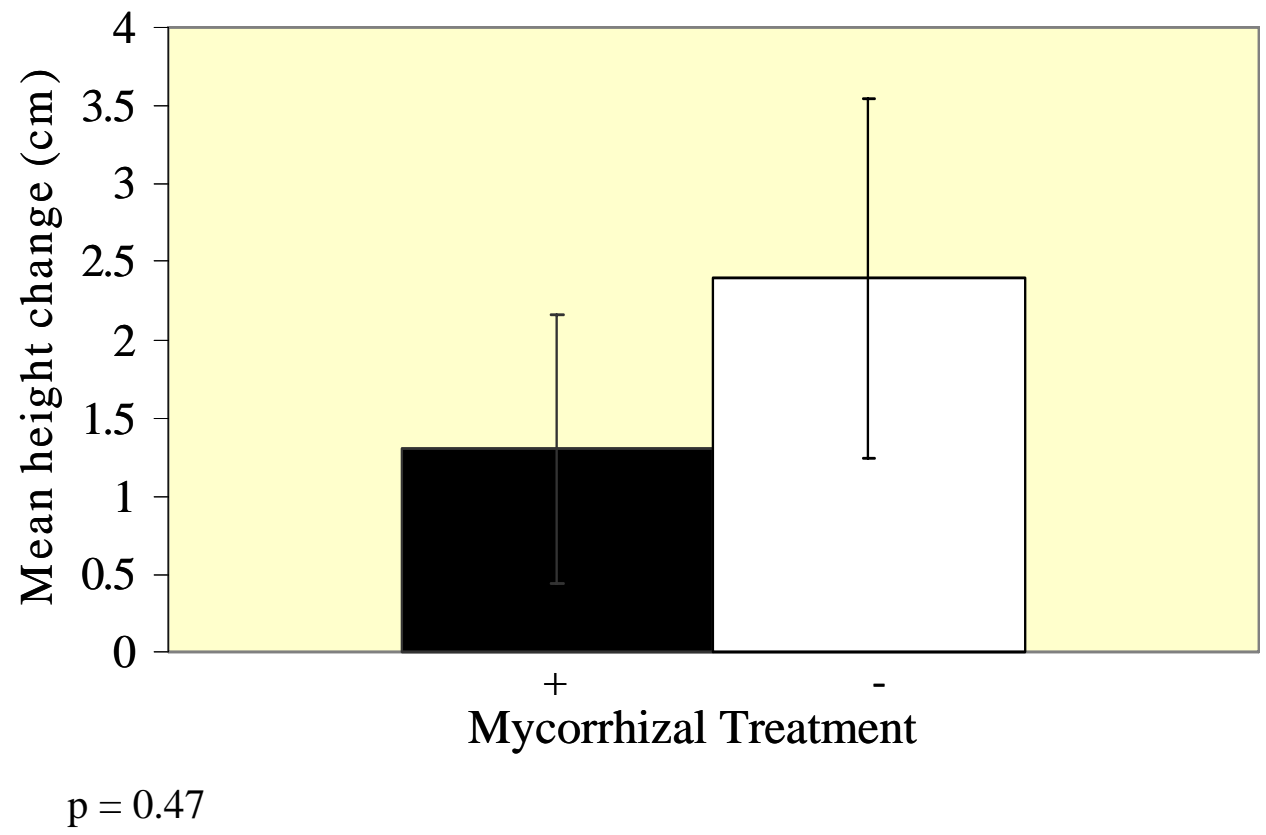


Figure 3.5. Latitudinal variations in shortwave energy load, in kilolangleys per year, between pole-facing (north-facing) and equator-facing (south-facing) slopes for each of four slope angles.

Adapted from Holland and Steyn (1975).

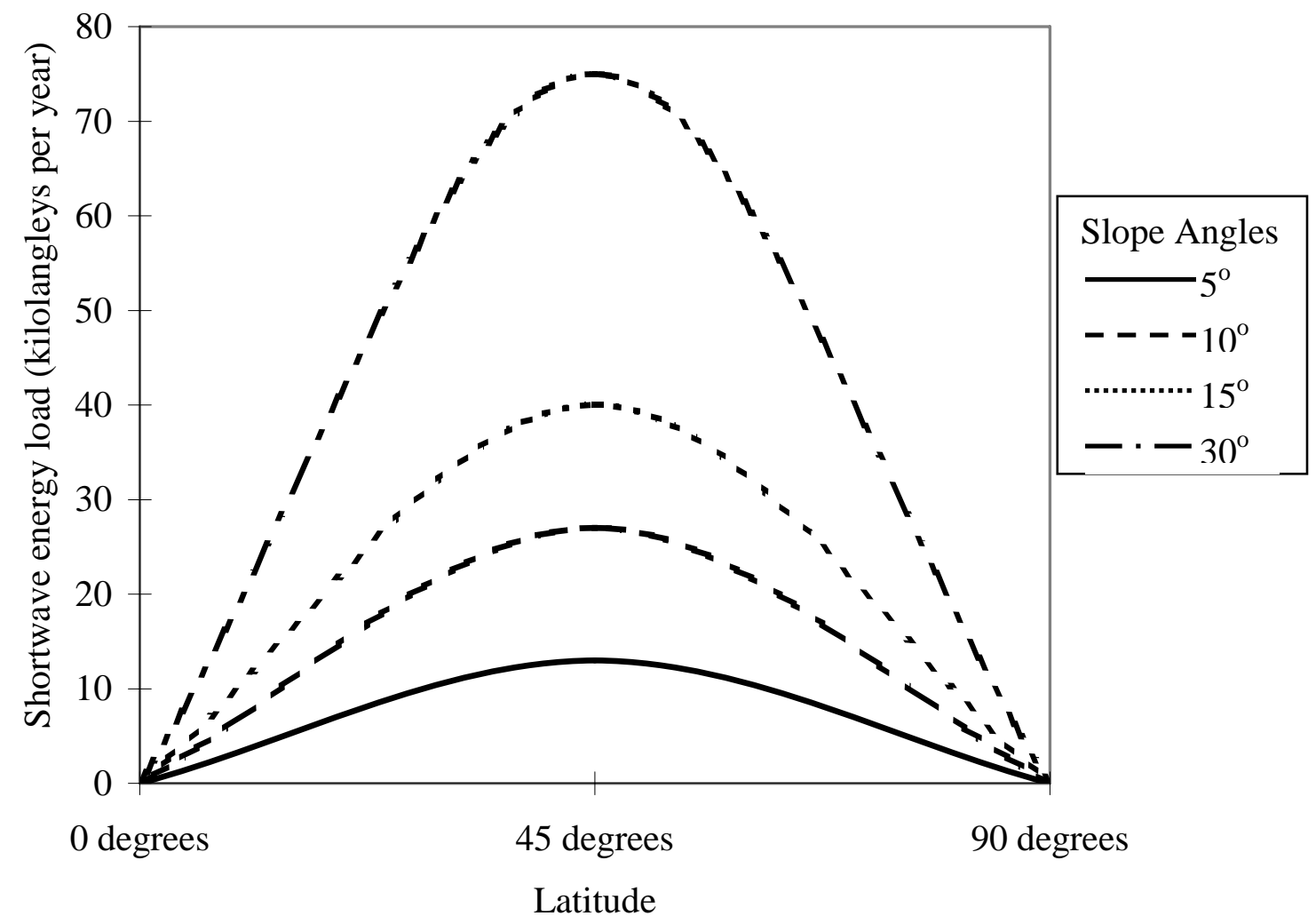


Table 3.1. Summative data of mortality and mean height of Rhus aromatica $(\mathrm{Ra})$ and Parthenocissus quinquefolia (Pq) cuttings treated with AM fungi (+/-) in roadside plots located along WV Route 50 near West Union.

\begin{tabular}{cclll}
\hline & & Number of & Mean & Mean \\
Plot & Level & Individuals & Height $(\mathrm{cm})$ & Leaf Number \\
\hline 1N & Pq+ & 0 & 0 & 0 \\
& Pq- & 0 & 0 & 0 \\
& Ra+ & 0 & 0 & 0 \\
& Ra- & 0 & 0 & 0 \\
1S & Pq+ & 2 & $\mathbf{5 . 2}$ & $\mathbf{1 . 5}$ \\
& Pq- & 4 & $\mathbf{4 . 7}$ & $\mathbf{1}$ \\
& Ra+ & $\mathbf{0}$ & $\mathbf{0}$ & $\mathbf{0}$ \\
& Ra- & $\mathbf{0}$ & $\mathbf{0}$ & $\mathbf{0}$ \\
2N & Pq+ & 0 & 0 & 0 \\
& Pq- & 0 & 0 & 0 \\
& Ra+ & 0 & 0 & 0 \\
& Ra- & 0 & 0 & 0 \\
2S & Pq+ & 0 & 0 & 0 \\
& Pq- & 0 & 0 & 0 \\
& Ra+ & 0 & 0 & 0 \\
& Ra- & 0 & 0 & 0 \\
\hline
\end{tabular}




\section{Literature Cited}

Boyce, S.G. and D.J. Neebe. 1959. Trees for planting on strip-mined land in Illinois. Technical paper 164. U.S. Forest Service, Ohio.

Eldridge, D.J., M. Westoby, and K.G. Holbrook. 1991. Soil-surface characteristics, microtopography and proximity to mature shrubs: Effects on survival of several cohorts of Atriplex vesicaria seedlings. Journal of Ecology 78: 357-364.

Harmon, P.J., D.I. Ford-Werntz, W.N. Grafton. 2001, in press. Checklist of the Vascular Flora of West Virginia. Division of Natural Resources, West Virginia Nongame Wildlife and Natural Heritage Program.

Hartmann, H.T., D.E. Kester, F.T. Davies, jr., and R.L. Geneve. 1997. Plant propagation: Principles and practices, $6^{\text {th }}$ edition. Prentice Hall, Upper Saddle River, NJ.

Hess, C.E. and W.E. Snyder. 1995. Interrupted mist found superior to constant mist in tests with cuttings. American Nurseryman Dec. 15: 11-12.

Holland, P.G. and D.G. Steyn. 1975. Vegetational responses to latitudinal variations in slope angle and aspect. Journal of Biogeography 2: 179-183.

Huxley, Anthony. 1992. The New Royal Horticultural Society Dictionary of Gardening, vol.4. The Stockton Press, NY.

Jonsson, G.B. and J.M. Zak. 1975. Propagation of sumac species for Massachusetts roadsides. American Nurseryman 142(6): 14-15, 24, 26, 28.

Li, X., J.M. Baskin, and C.C. Baskin. 1999. Contrasting soil seed-bank dynamics in relation to local recruitment modes in two clonal shrubs, Rhus aromatica Ait. and Rhus glabra L. (Anacardiaceae). American Midland Naturalist 142: 266-280. 
Mack, R.N., D. Simberloff, W.M. Lonsdale, H. Evans, M. Clut, and F.A. Bazzaz. 2000. Biotic invasions: causes, epidemiology, global consequences, and control. Ecological Applications 10(3): 689-710.

McCully, W.G. 2000. Utilizing the ecotype concept: an insight into native plant establishment. In: Harper-Lore, B. and M. Wilson, editors. Roadside use of native plants. Island Press, Washington D.C.

Morano, L.D. and M.A. Walker. 1995. Soils and plant communities associated with three Vitis species. American Midland Naturalist 134(2): 254-263.

Reeves, F.B., D. Wagner, T. Moorman, and J. Kiel. 1979. The role of endomycorrhizae in revegetation practices in the semi-arid West. A comparison of incidence of mycorrhizae in severely disturbed vs. natural environments. American Journal of Botany 66(1): 6-13.

Ridenour, W.M. and R.M. Callaway. 2001. The relative importance of Allelopathy in interference: The effects of an invasive weed on a native bunchgrass. Oecologia 126: 444-450.

Robinson, T.S. 1966. Effects of canopy density and slope exposure on the subcanopy microenvironment of a northern hardwood forest. The American Midland Naturalist 75(2): 339-346.

Rombough, L. 2002. The grape grower: A guide to organic viticulture. Chelsea Green Publishing, White River Junction, VT. 
Schutzman, B. 2004. Landscape plant propagation information (http://hort.ifas.ufl.edu/lppi/). University of Florida, Institution of Food and Agricultural Sciences: Environmental Horticulture, Gainesville, FL 32611.

TransSafety. 1997. Survey finds state DOTs feel biodiversity is a new issue in transportation development projects. Road Management and Engineering Journal, Sept. 2: 1-2 (http://www.usroads.com). TransSafety, Inc., Sequim, WA.

USDA, FS. 1998. Eastern region invasive plants, ranked by degree of invasiveness as based on information from states. Forest Service technical paper. USDA-FS, Washington D.C.

USDA, NRCS. 2002. The PLANTS Database, version 3.5 (http://plants.usda.gov). National Plants Data Center, Baton Rouge, LA 70874-4490.

Wang, S.Y., M. Faust, M.J. Line. 2004. Apical dominance in Malus domestica Borkh: the possible role of Indole-3-Acetic-Acid. ARS report 0000033453. USDA, Agricultural Research Service, Fruit Laboratory. Beltsville, MD 20705. 


\section{Curriculum Vitae}

SARAH WENNERBERG

July 2005

West Virginia University

Department of Biology

Post Office Box 6057

Morgantown, WV 26506

304.293.5201 ext. 31454
Post Office Box 1244

Dellslow, WV 26531

304.296 .7554

swennerb@mix.wvu.edu

June 2005

West Virginia University, Eberly College of Arts and Sciences, Morgantown, WV

- Master of Science in Environmental and Evolutionary Biology

December 2004

West Virginia University, College of Human Resources and Education, Morgantown, WV

- Master of Arts in Educational Leadership Studies

May 2001

Ball State University, College of Sciences and Humanities, Muncie, IN

- Bachelor of Science in Biology, Botany option

May 1998

Fergus Falls Community College, Fergus Falls, MN

- Associate of Arts degree in Liberal Arts

September 1995-March 1996

Alexandria Technical College, Alexandria, MN

- Two quarters of study in Interior Design

\section{$\underline{\text { RESEARCH }}$}

\section{a. Focus}

My research investigated the probable suitability of native plants to replace the West Virginia Department of Highways' planting mix that currently contains non-native and some invasive species. Various propagation techniques and planting environments were tested. The project originated from collaborative studies between several departments at West Virginia University and the West Virginia Department of Highways. 
b. Presentations

Wennerberg, S.B. Propagation and field assessment of Rhus aromatica, Vitis riparia, and Parthenocissus quinquefolia for roadside revegetation. West Virginia Academy of Sciences annual conference. West Virginia University, Morgantown, WV. April 2005.

Wennerberg, S.B. Propagation and field studies of West Virginia native plant species for roadside revegetation. West Virginia University, Department of Biology seminar, September 2004.

Wennerberg, S.B. Propagation and proposed field studies of four West Virginia native species for roadside revegetation. West Virginia University, Department of Biology seminar, October, 2003.

Wennerberg, S., K. Klugh, C. Springer, and E. Pyle. Poster. Ecological education enrichment in grades 5-10 of West Virginia schools by NSF GK-12 teaching fellows. Ecological Society of America annual conference. Savanna, GA, August 2003.

Wennerberg, S.B. and D.I. Ford-Werntz. Proposed propagation and field studies of four West Virginia native species for roadside revegetation. Poster. West Virginia Academy of Sciences annual conference. West Virginia Wesleyan College, Buckhannon, WV, April 2002.

Wennerberg, S.B. and D.I. Ford-Werntz. Proposed propagation and field studies of four West Virginia native species for roadside revegetation. Poster. West Virginia University Horizons Poster Symposium. West Virginia University, Morgantown, WV, April 2002.

\section{WORK AND TEACHING EXPERIENCE}

July 2004 - July 2005

West Virginia University, Morgantown, WV. Assistant Herbarium Curator. Cataloged herbarium specimens in FoxPro database; supervised progress of volunteers and student employees; prioritized workloads for volunteers and student-workers; filled specimen loan requests; maintained spreadsheets for workers' hours and herbarium services; served as the general contact person for those wishing to visit the herbarium or requesting information; directed herbarium tours for workshops, classes, and garden clubs; developed herbarium programs for visitors as needed. 
May 2003 - December 2004

USDA-NRCS, National Plant Data Center, Baton Rouge, LA. Graduate Student Temporary Employee, duty station Morgantown, WV.

Collected and entered data into Microsoft Access Databases and wrote plant guides for publication on the National PLANTS Online Database. The primary database project recorded state nativity status for United States native invasive plants.

January 2004 - May 2004

Center for Advising and Records, West Virginia University, Morgantown, WV. Intern.

Shadowed undergraduate advising sessions in the College of Human Resources and Education; converted PRAXIS score reports into Microsoft Access format; created and wrote advisor handbook; participated in visitation days for the college; attended weekly staff meetings.

June 2002 - June 2003

West Virginia University, Morgantown, WV. National Science Foundation-Sponsored GK-12 Teaching Fellow, TIGERS program (Teams of Interdisciplinary Graduate Fellows Engaged to $\underline{R} e$-invigorate $\underline{\text { Students}) \text {. }}$

Created action plans in accordance to state content standards for science classrooms in middle and high schools; coordinated activities based on curricular needs of middle and high school teachers; traveled to middle and high school science classrooms to lead students in activities; presented information about the fellowship program at the West Virginia Science Teachers Association and Ecological Society of America annual conferences.

August 2001 - May 2002

West Virginia University, Morgantown, WV. Teaching Assistant.

Led lab activities for Principles of Biology (BIOL 115) and The Total Science Experience (Biology 321); designed quizzes, edited and graded manuscripts; taught statistical analysis to freshman, sophomore, and junior biology majors.

BIOL 115: Principles of Biology is the introductory course for biology majors. The course gives a fundamental overview of biological aspects emphasized in the program: organismal biology, cell and molecular biology, and ecology and evolution.

BIOL 321 Lab: The Total Science Experience is the lab component of the final biology course of core requirements in the Biology Program. The lecture portion of the course expands upon the ecology and evolution component of BIOL 115. In lab, students draw from their knowledge gained from previous biology, chemistry, physics, and math courses to design and conduct their own biological research experiment. Students also collect and analyze their data. The final products of this course are a written manuscript and poster or oral presentation of students' research. 
March 2000-June 2001

Spence Restoration Nursery, Muncie, IN. Greenhouse Worker.

Prepared native plant orders for shipping or planting; propagated seeds for greenhouse production; performed general care duties of the greenhouses and aquatic beds such as weeding, watering, and cleaning.

August 1999 - July 2001

Ball State University, Muncie, IN. Herbarium Student-Worker.

Verified and updated the taxonomy of incoming and current specimens; assigned accession numbers; catalogued and filed incoming herbarium specimens; converted database to Microsoft Access database; pulled and prepared specimens for use in Plant Taxonomy course.

October 1996 - May 1998

Center for Lifelong Learning, Fergus Falls Community College, Fergus Falls, MN. Office Assistant.

Assisted with the planning and implementation of continuing education courses including Real Estate (Re)Certification, Certified Nursing Assistant, and grant writing classes; performed general office duties and bulk mailings; coordinated the "College for Kids" summer arts program; maintained address database of all course participants; prepared quarterly financial reports on Lotus 1-2-3; received Work-Study Student of the Year award in 1998.

\section{$\underline{\text { SERVICE }}$}

July 2001 - present

West Virginia University Arboretum, Morgantown, WV. Volunteer tour guide.

December 2004

Habitat for Humanity, Fairmont, WV. Volunteer.

October 2004

West Virginia University, Life Sciences Building, Morgantown, WV. Coordinator of volunteer clean-up day.

September 2004

West Virginia Science Teachers Association, annual conference, Morgantown, WV. Workshop leader.

January 1997 - April 1997

Lincoln Elementary School, Fergus Falls, MN. First-grade classroom volunteer.

August 1994 - December 1994

Habitat for Humanity, Willmar, MN. Volunteer. 